\title{
Gas and aerosol carbon in California: comparison of measurements and model predictions in Pasadena and Bakersfield
}

\author{
K. R. Baker ${ }^{1}$, A. G. Carlton ${ }^{2}$, T. E. Kleindienst ${ }^{3}$, J. H. Offenberg ${ }^{3}$, M. R. Beaver ${ }^{3}$, D. R. Gentner ${ }^{4}$, A. H. Goldstein ${ }^{5}$,

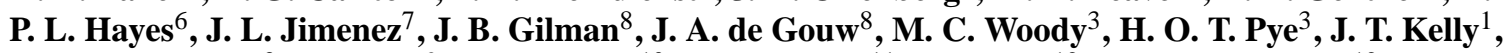 \\ M. Lewandowski ${ }^{3}$, M. Jaoui ${ }^{9}$, P. S. Stevens ${ }^{10}$, W. H. Brune ${ }^{11}$, Y.-H. Lin ${ }^{12}$, C. L. Rubitschun ${ }^{12}$, and J. D. Surratt ${ }^{12}$ \\ ${ }^{1}$ Office of Air Quality Planning and Standards, US Environmental Protection Agency, Research Triangle Park, NC, USA \\ ${ }^{2}$ Dept. of Environmental Sciences, Rutgers University, New Brunswick, NJ, USA \\ ${ }^{3}$ Office of Research and Development, US Environmental Protection Agency, Research Triangle Park, NC, USA \\ ${ }^{4}$ Department of Chemical and Environmental Engineering, Yale University, New Haven, CT, USA \\ ${ }^{5}$ Department of Civil and Environmental Engineering, University of California, Berkeley, CA, USA \\ ${ }^{6}$ Département de Chimie, Université de Montréal, Montréal, Québec, Canada \\ ${ }^{7}$ Department of Chemistry \& Biochemistry, and CIRES, University of Colorado, Boulder, Colorado, USA \\ ${ }^{8}$ Chemical Sciences Division, Earth System Research Laboratory, National Oceanic and Atmospheric Administration, \\ Boulder, CO, USA \\ ${ }^{9}$ Alion Science and Technology, Inc., Research Triangle Park, NC, USA \\ ${ }^{10}$ Center for Research in Environmental Science, School of Public and Environmental Affairs and Department of Chemistry, \\ Indiana University, Bloomington, IN, USA \\ ${ }^{11}$ Department of Meteorology, Pennsylvania State University, University Park, PA, USA \\ ${ }^{12}$ Department of Environmental Sciences and Engineering, Gillings School of Global Public Health, University of North \\ Carolina at Chapel Hill, Chapel Hill, NC, USA
}

Correspondence to: K. R. Baker (baker.kirk@epa.gov)

Received: 21 November 2014 - Published in Atmos. Chem. Phys. Discuss.: 7 January 2015

Revised: 6 April 2015 - Accepted: 23 April 2015 - Published: 12 May 2015

\begin{abstract}
Co-located measurements of fine particulate matter $\left(\mathrm{PM}_{2.5}\right)$ organic carbon $(\mathrm{OC})$, elemental carbon, radiocarbon $\left({ }^{14} \mathrm{C}\right.$ ), speciated volatile organic compounds (VOCs), and $\mathrm{OH}$ radicals during the CalNex field campaign provide a unique opportunity to evaluate the Community Multiscale Air Quality (CMAQ) model's representation of organic species from VOCs to particles. Episode average daily $23 \mathrm{~h}$ average ${ }^{14} \mathrm{C}$ analysis indicates $\mathrm{PM}_{2.5}$ carbon at Pasadena and Bakersfield during the CalNex field campaign was evenly split between contemporary and fossil origins. CMAQ predicts a higher contemporary carbon fraction than indicated by the ${ }^{14} \mathrm{C}$ analysis at both locations. The model underestimates measured $\mathrm{PM}_{2.5}$ organic carbon at both sites with very little (7\% in Pasadena) of the modeled mass represented by secondary production, which contrasts with the ambient-based SOC / OC fraction of $63 \%$ at Pasadena.
\end{abstract}

Measurements and predictions of gas-phase anthropogenic species, such as toluene and xylenes, are generally within a factor of 2, but the corresponding SOC tracer (2,3dihydroxy-4-oxo-pentanoic acid) is systematically underpredicted by more than a factor of 2. Monoterpene VOCs and SOCs are underestimated at both sites. Isoprene is underestimated at Pasadena and overpredicted at Bakersfield and isoprene SOC mass is underestimated at both sites. Systematic model underestimates in SOC mass coupled with reasonable skill (typically within a factor of 2) in predicting hydroxyl radical and VOC gas-phase precursors suggest error(s) in the parameterization of semivolatile gases to form SOC. Yield values $(\alpha)$ applied to semivolatile partitioning species were increased by a factor of 4 in CMAQ for a sensitivity simulation, taking into account recent findings of underestimated yields in chamber experiments due to gas wall losses. This sensitivity resulted in improved model perfor- 
mance for $\mathrm{PM}_{2.5}$ organic carbon at both field study locations and at routine monitor network sites in California. Modeled percent secondary contribution (22\% at Pasadena) becomes closer to ambient-based estimates but still contains a higher primary fraction than observed.

\section{Introduction}

Secondary organic aerosol (SOA) forms in the atmosphere during the gas-phase photooxidation of volatile organic compounds (VOCs) that produce semivolatile and water-soluble gases that condense to form new particles or partition to preexisting aerosol mass (Ervens et al., 2011). SOA contributes to the atmospheric fine particulate matter $\left(\mathrm{PM}_{2.5}\right)$ burden, with subsequent effects on air quality, visibility, and climate (Hallquist et al., 2009). Despite its importance and abundance, ambient SOA mass is not well characterized by atmospheric models (Wagstrom et al., 2014). For example, the Community Multiscale Air Quality (CMAQ) model consistently underpredicts surface SOA mass concentrations for a variety of seasons and locations when compared to ambient observational estimates (Carlton and Baker, 2011; Carlton et al., 2010; Hayes et al., 2014; Zhang et al., 2014a).

SOA formation and the preceding gas-phase photooxidation chemistry are complex and often involve multiple oxidation steps in the gas, aqueous, and particle phase as well as accretion reactions in the particle phase that yield high molecular weight products. However, three-dimensional photochemical models must represent the gas-phase chemistry and SOA formation in a simplified fashion for computational efficiency (Barsanti et al., 2013). Gas-phase chemical mechanisms employ "lumped" VOC species, categorized primarily according to reactivity (e.g., reaction rate constants with the $\mathrm{OH}$ radical) (Carter, 2000; Yarwood et al., 2005 ), not product volatility or solubility. Condensable SOAforming oxidation products are typically represented with two products in the standard versions of publically available and routinely applied photochemical modeling systems such as GEOS-CHEM (Chung and Seinfeld, 2002; Henze and Seinfeld, 2006) and WRF-CHEM (Grell et al., 2005) and those employed in regulatory applications for rule making such as CMAQ (Carlton et al., 2010) and the Comprehensive Air Quality Model with extensions (CAMx) (ENVIRON, 2014). Given the relationships between precursor VOC, $\mathrm{OH}$ radical abundance, and SOA formation, it is important to simultaneously evaluate the model representation of all three within the context of how organic species evolve in the atmosphere to diagnose persistent SOA model bias.

Recent studies have shown that warm season SOA mass concentrations are usually greater than primary organic aerosol (POA) mass in the Los Angeles (Docherty et al., 2008; Hersey et al., 2011; Hayes et al., 2013) and Bakersfield (Liu et al., 2012) areas. Gas-to-particle condensation of VOC oxidation products dominates formation of summer
SOA in Bakersfield (Liu et al., 2012; Zhao et al., 2013) and up to one-third of nighttime organic aerosols (OA) in Bakersfield are organic nitrates (Rollins et al., 2012). Sources of warm season OA in Bakersfield include fossil fuel combustion, vegetative detritus, petroleum operations, biogenic emissions, and cooking (Liu et al., 2012; Zhao et al., 2013). Despite numerous studies based on observations and models, less consensus exists regarding the largest sources of warm season SOA at Pasadena. Bahreini et al. (2012) concluded that SOA at Pasadena is largely derived from gasoline engines with minimal biogenic and diesel fuel contribution (Bahreini et al., 2012). Others concluded large contributions from gasoline fuel combustion to SOA but also found notable contributions from diesel fuel combustion, cooking, and other sources (Gentner et al., 2012; Hayes et al., 2013). Zotter at al. (2014) conclude that $70 \%$ of the SOA in the urban plume in Pasadena is due to fossil sources and that at least $25 \%$ of the non-fossil carbon is due to cooking sources. Lower volatility VOC measurements made at Pasadena have been estimated to produce approximately $30 \%$ of fresh SOA in the afternoon with a large contribution to these low volatility VOC from petroleum sources other than on-road vehicles (Zhao et al., 2014).

Chemical measurements of $\mathrm{PM}_{2.5}$ carbon, fossil and contemporary aerosol carbon fraction, OC and its components, SOC tracers, and speciated VOCs taken as part of the 2010 California Research at the Nexus of Air Quality and Climate Change (CalNex) field study in central and southern California (Ryerson et al., 2013) provide a unique opportunity to quantitatively evaluate modeled organic predictions. These special study data combined with routine $\mathrm{PM}_{2.5}$ OC measurements in California are compared with model estimates to gauge how well the modeling system captures the gas and aerosol carbon burden using the standard CMAQ aerosol approach. The SOC mechanism in the base version of CMAQ lends itself well to comparison with chemical tracers because it retains chemical identity traceable to the precursor VOC (Carlton et al., 2010). Finally, a CMAQ sensitivity simulation was performed in which the yields of semivolatile gases from VOC oxidation were increased by a factor of 4 (Zhang et al., 2014b) to determine whether this may ameliorate the model underprediction of secondary organic carbon (SOC) seen here and in other studies (Ensberg et al., 2014).

\section{Methods}

Predictions of speciated VOC, speciated SOC, and aerosolphase carbon are simultaneously compared to co-located ambient measurements at two surface locations, one in Los Angeles County (Pasadena) and one in the San Joaquin Valley (Bakersfield) air basin. The CMAQ photochemical model is applied with a fine grid resolution ( $4 \mathrm{~km}$ sized grid cells) using emissions from the 2011 National Emissions Inventory and 2010 specific point source information where available. 


\subsection{Model background}

CMAQ version 5.0.2 (www.cmaq-model.org) was applied to estimate air quality in California from 5 May to 1 July 2010, coincident with the CalNex study. Gas-phase chemistry is simulated with the SAPRC07TB condensed mechanism (Hutzell et al., 2012) and aqueous-phase chemistry that oxidizes sulfur, methylglyoxal (MGLY), and glyoxal (Carlton et al., 2008; Sarwar et al., 2013). The AERO6 aerosol chemistry module includes ISORROPIAII (Fountoukis and Nenes, 2007) inorganic chemistry and partitioning. The modeling system generally does well capturing ambient inorganic gases and $\mathrm{PM}_{2.5}$ species during this time period at Pasadena and Bakersfield (Kelly et al., 2014; Markovic et al., 2014).

Model-predicted OC species are shown in Fig. 1 by volatility bin $\left(\log\right.$ of $\left.\mathrm{C}^{*}\right)$ and $\mathrm{O}: \mathrm{C}$ ratio (see Supplement for related details). Aqueous-phase species are shown with blue circles, species largely fossil in origin are colored brown, and those non-fossil in origin are green. A general trend of increasing $\mathrm{O}: \mathrm{C}$ ratio as volatility decreases is consistent with laboratory and field measurements (Jimenez et al., 2009). The placement of the MGLY geminal diol vertically above gas-phase MGLY in Fig. 1 represents hydration processes. Aqueous-phase organic chemistry represents multiple processes, including functionalization and oligomerization, because some photooxidation products are small carboxylic acids and others are high molecular weight species (Tan et al., 2010; Carlton et al., 2007).

VOC precursors for SOA include isoprene, monoterpenes, sesquiterpenes, xylenes, toluene, benzene, alkanes, glyoxal, and methylglyoxal (Fig. 1 right panel). Benzene, toluene, and xylene form SOA precursors with high- $\mathrm{NO}_{x}$ $\left(\mathrm{RO}_{2}+\mathrm{NO}\right)$ and low- $\mathrm{NO}_{x}\left(\mathrm{RO}_{2}+\mathrm{HO}_{2}\right)$ specific yields (Carlton et al., 2010). CMAQ converts these precursors into multiple semivolatile products (Fig. 1 middle panel) after a single oxidation step. These multiple products vary in terms of assigned volatility and oxygen-to-carbon $(\mathrm{O}: \mathrm{C})$ ratio. When semivolatile SOA mass oligomerizes in CMAQ the SOA identity is lost and becomes classified only as anthropogenic or biogenic, dependent on the VOC precursor (see Fig. S2 in the Supplement). After oligomerization, the saturation vapor pressure $\left(\mathrm{C}^{*}\right)$ and $\mathrm{OM}$ : $\mathrm{OC}$ ratio associated with all of the two-product semivolatile SOA species change from the individual values to the values assigned for non-volatile, non-partitioning SOA mass $\left(\mathrm{C}^{*} \approx 0 ; \mathrm{OM}: \mathrm{OC}=2.1\right)(\mathrm{Carl}-$ ton et al., 2010).

CMAQ VOCs and SOC species are paired in time and space with measurements (Table S2 in the Supplement). Modeled predictions are averaged temporally to match observations and extracted from the grid cell where the monitor is located. Modeled toluene and xylene SOC are aggregated to match the measured SOC tracer (2,3-dihydroxy4-oxopentanoic acid) which is known to represent products from both compounds and potentially other methylated aromatics (Kleindienst et al., 2004). Because the original
VOCs contributing to oligomerized species are not tracked by CMAQ, biogenic oligomerized species mass is apportioned to parent VOC based on the fraction each semivolatile SOC species contributes to the total semivolatile (nonoligomerized) biogenic SOC at that time and location. The same technique is applied to anthropogenic SOC.

\subsection{Model application}

The model domain covers the state of California and part of northwest Mexico using $4 \mathrm{~km}$ square sized grid cells (Fig. S1 in the Supplement). The vertical domain extends to $50 \mathrm{mb}$ using 34 layers (layer 1 top $\sim 35 \mathrm{~m}$ ) with most resolution in the boundary layer. Initial and boundary conditions are from a coarser CMAQ simulation that used 3-hourly boundary inflow from a GEOS-Chem (v8-03-02) global model (http://acmg.seas.harvard.edu/geos/) simulation for the same period (Henderson et al., 2014). The coarser continental US CMAQ simulation was run continuously from December 2009 through this study period and the first week of the finer $4 \mathrm{~km}$ CMAQ simulation was not used to minimize the influence of initial chemical conditions. Gridded meteorological variables are generated using the Weather Research and Forecasting model (WRF), Advanced Research WRF core (ARW) version 3.1 (Skamarock et al., 2008). Surface meteorology including temperature, wind speed, and wind direction and daytime mixing layer height were well characterized by WRF in central and southern California during this period (Baker et al., 2013).

Emissions are processed to hourly gridded input for CMAQ with the Sparse Matrix Operator Kernel Emissions (SMOKE) modeling system (http://www.cmascenter. org/smoke/). Solar radiation and temperature estimated by the WRF model are used as input to the Biogenic Emission Inventory System (BEIS) v3.14 to generate hourly emissions estimates of biogenic speciated VOC and NO (Carlton and Baker, 2011). Continuous emissions monitor data are used in the modeling to reflect 2010 emissions information for electrical generating units and other point sources that provide that information. Day-specific fires are represented but minimally impacted air quality during this period (Hayes et al., 2013). Mobile source emissions were generated using the SMOKE-MOVES integration approach (United States Environmental Protection Agency, 2014) and then interpolated between totals provided by the California Air Resources Board for 2007 and 2011. Other anthropogenic emissions are based on the 2011 National Emissions Inventory (NEI) version 1 (US Environmental Protection Agency, 2014). Primary mass associated with carbon (noncarbon organic mass) is estimated based on sector-specific organic matter-to-organic carbon (OM: OC) ratios (Simon and Bhave, 2012).

Emissions of primarily emitted $\mathrm{PM}_{2.5} \mathrm{OC}$ and the sum of anthropogenic SOA precursors benzene, toluene, and xylenes (BTX) are shown in Table 1 by source sector and 


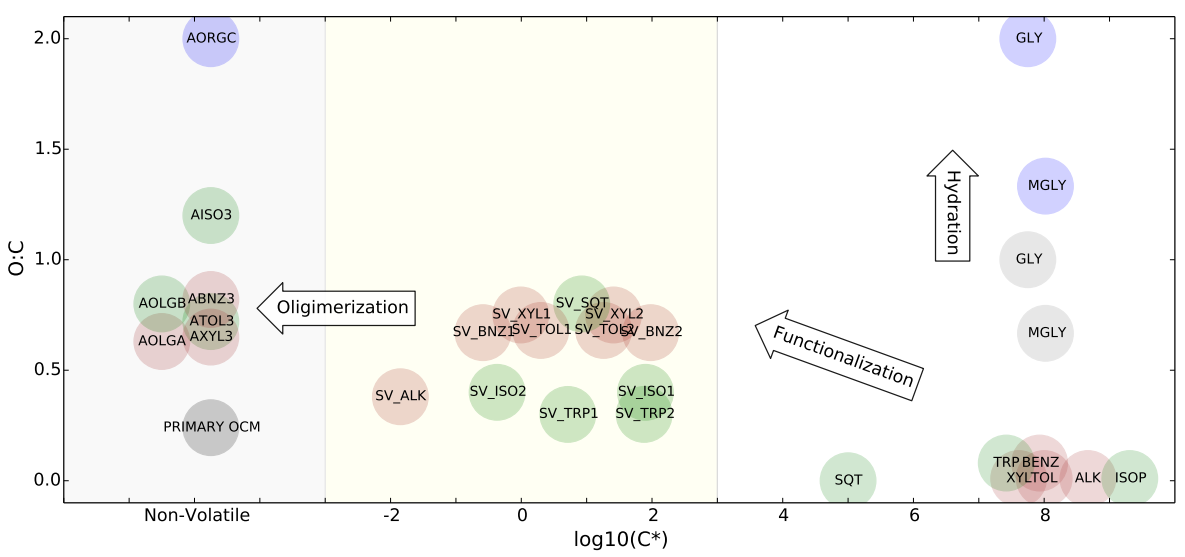

Figure 1. Gas (right panel), semivolatile (middle panel), and particle-phase (left panel) CMAQ organic carbon shown by saturation vapor pressure and $\mathrm{O}: \mathrm{C}$ ratio. Compounds shown in blue exist in the aqueous phase, those in brown are generally fossil in origin, those in green are generally contemporary in origin, and those in gray both contemporary and fossil in origin. Other known processes such as fragmentation are not shown as they are not currently represented in the modeling system.

Table 1. Episode total anthropogenic emissions of primarily emitted $\mathrm{PM}_{2.5}$ organic carbon and the sum of benzene, toluene, and xylenes by emission sector group. The Los Angeles (LA) total includes Los Angeles and Orange counties. The southern San Joaquin Valley (SSJV) total includes Kern, Fresno, Kings, and Tulare counties. Residential wood combustion, fugitives, and non-point area $\mathrm{PM}_{2.5} \mathrm{emissions}$ are largely contemporary in origin.

\begin{tabular}{|c|c|c|c|c|c|c|c|c|}
\hline \multirow[b]{2}{*}{ Sector } & \multicolumn{4}{|c|}{ Primarily emitted $\mathrm{PM}_{2.5}$ organic carbon } & \multicolumn{4}{|c|}{ Benzene + toluene + xylenes } \\
\hline & SSJV (tons) & $\operatorname{SSJV}(\%)$ & LA (tons) & LA $(\%)$ & SSJV (tons) & SSJV (\%) & LA (tons) & LA $(\%)$ \\
\hline Non-point area & 139.9 & 33.8 & 410.1 & 40.8 & 326.7 & 37.2 & 1229.3 & 35.8 \\
\hline On-road mobile & 73.3 & 17.7 & 263.6 & 26.2 & 273.5 & 31.2 & 1190.9 & 34.6 \\
\hline Non-road mobile & 23.9 & 5.8 & 161.4 & 16.1 & 170.1 & 19.4 & 822.3 & 23.9 \\
\hline Point: non-electrical generating & 61.3 & 14.8 & 56.3 & 5.6 & 68.3 & 7.8 & 177.7 & 5.2 \\
\hline Point: non-electrical generating & 54.1 & 13.1 & 82.7 & 8.2 & 2.0 & 0.2 & 3.2 & 0.1 \\
\hline Oil and gas exploration and related & 28.5 & 6.9 & 0.0 & 0.0 & 34.2 & 3.9 & 1.1 & 0.0 \\
\hline Fugitive dust & 24.9 & 6.0 & 18.1 & 1.8 & 0.0 & 0.0 & 0.0 & 0.0 \\
\hline Commercial marine and rail & 3.8 & 0.9 & 11.4 & 1.1 & 2.6 & 0.3 & 12.8 & 0.4 \\
\hline Point: electrical generating & 4.3 & 1.0 & 1.7 & 0.2 & 0.1 & 0.0 & 1.0 & 0.0 \\
\hline Total contemporary carbon & 218.9 & 52.9 & 510.9 & 50.8 & 2.0 & 0.2 & 3.2 & 0.1 \\
\hline Total fossil carbon & 195.2 & 47.1 & 494.5 & 49.2 & 875.3 & 99.8 & 3435.1 & 99.9 \\
\hline Total & 414.1 & & 1005.3 & & 877.4 & & 3438.3 & \\
\hline
\end{tabular}

area. Here, the southern San Joaquin Valley includes emissions from Kern, Tulare, Kings, and Fresno counties, and the Los Angeles area includes emissions from Los Angeles and Orange counties. BTX emissions in both areas are dominated by mobile sources (on-road and off-road) and area sources such as solvent utilization and waste disposal (Table S1). Primary OC emissions are largely commercial cooking (nonpoint area) in both locations with notable contributions from various types of stationary point and mobile sources. BTX emissions are almost completely fossil in origin and primarily emitted OC is split fairly evenly between contemporary and fossil origin in these areas based on the 2011 version 1 NEI (Table 1).

\subsection{Sampling and analysis methods}

CalNex ground-based measurements took place in Pasadena, CA, from 15 May to 15 June 2010 and in Bakersfield, CA, from 15 May to 30 June 2010. The Bakersfield sampling site was located in a transition area of southeast Bakersfield between the city center and areas of agricultural activity. The Pasadena sampling site was located on the California Institute of Technology campus with the Los Angeles metropolitan area to the southwest and San Gabriel Mountains directly north (see Fig. S3).

An ambient-based approach is used here to estimate secondary OC from individual or groups of similar hydrocarbons (Kleindienst et al., 2010). Concentrations of specific compounds, tracers, are determined and used to estimate 
SOC contributions from the particular source groups based on measured laboratory tracer-to-SOC mass fractions (Kleindienst et al., 2007). Filter-based particulate matter sampling conducted at each site for $23 \mathrm{~h}$ periods starting at midnight (PDT) on the designated sampling day was used for tracerbased organic aerosol characterization. In total, there were 32 filter samples from Pasadena and 36 from the Bakersfield site (Lewandowski et al., 2013). The filter sampling protocols have been described in detail elsewhere (Kleindienst et al., 2010). For the analysis of the SOC tracer compounds, filters and field blanks were treated using the derivatization method described by Kleindienst et al. (2007). The mass spectral analysis for the organic compounds used as secondary molecular tracers has been described (Edney et al., 2003). The method detection limit (MDL) for the SOC tracer species is $0.1 \mathrm{ng} \mathrm{m}^{-3}$. Additional details of this methodology are provided in the Supplement.

OC and elemental carbon (EC) concentrations were determined using the thermal-optical transmittance (TOT) method (Birch and Cary, 1996) from $1.54 \mathrm{~cm}^{2}$ punches of quartz filters collected concurrent with the filters used for tracer analyses (hereafter referred to as UNC/EPA OC). The outer non-loaded rings were removed from filter samples and then sent to Woods Hole Oceanographic Institute Accelerator Mass Spectrometry for ${ }^{14} \mathrm{C}$ analysis. The fraction of modern carbon is provided for each daily total $\mathrm{PM}_{2.5}$ carbon sample (Geron, 2009). The modern carbon fraction is expressed as a percentage of an oxalic acid standard material that represents the carbon isotopic ratio for wood growth during 1890 (Stuiver, 1983). To account for the atmospheric ${ }^{14} \mathrm{C}$ enhancement due to nuclear bomb testing in the 1950s and 1960s, a factor of 1.044 (Zotter et al., 2014) was used to calculate the contemporary carbon fraction from the measured modern carbon result (Lewis et al., 2004; Zotter et al., 2014).

Two VOC data sets (one canister based and one in situ) from each site were used in this analysis. Three-hour integrated (06:00-09:00 PDT) canister samples for VOC analysis were collected at both sites. A total of 41 samples were collected at the Bakersfield site and 31 at Pasadena. The offline VOC analysis details are given in the Supplement. In Bakersfield, online VOC mixing ratios were collected for $30 \mathrm{~min}$ on the hour and analyzed via gas chromatography-flame ionization detector (GC-FID) and gas chromatography-mass spectrometry (GC-MS) (Gentner et al., 2012). In Pasadena, online VOC measurements were collected for $5 \mathrm{~min}$ every $30 \mathrm{~min}$ and analyzed via GC-MS (Borbon et al., 2013; Gilman et al., 2010). Carbon monoxide measurements at Pasadena were determined using UV fluorescence (Gerbig et al., 1999).

Hydroxyl $(\mathrm{OH})$ and hydroperoxyl $\left(\mathrm{HO}_{2}\right)$ radical measurements were made at both locations using fluorescence assay with gas expansion (FAGE). The Bakersfield $\mathrm{OH}$ measurements used in this analysis were collected using the $\mathrm{OH}_{\text {chem }}$ method from the Penn State ground-based FAGE instrument (Mao et al., 2012). The Pasadena hydroperoxyl observations were made using the Indiana University FAGE instrument (Dusanter et al., 2009). $\mathrm{HO}_{2}$ measurements from both instruments could contain an interference from various $\mathrm{RO}_{2}$; therefore, when comparing the model output with the observations the sum of modeled $\mathrm{HO}_{2}$ and $\mathrm{RO}_{2}$ has been used (Griffith et al., 2013).

OC measurements from nearby Chemical Speciation Network (CSN) sites in Pasadena and Bakersfield were also used for comparison purposes. The Los Angeles CSN site (60371103) was approximately $14 \mathrm{~km}$ from the CalNex site, and the Bakersfield CSN site (60290014) was approximately $5 \mathrm{~km}$ from the CalNex site (see Fig. S3a and b in the Supplement). The CSN network uses quartz-fiber filters and analyzes the carbon offline using the thermal-optical reflectance (TOR) method. Aerodyne high-resolution timeof-flight aerosol mass spectrometer (AMS) measurements of $\mathrm{PM}_{1} \mathrm{OC}$ made at Pasadena are described in Hayes et al. (2013) and online Sunset Lab Inc. $\mathrm{PM}_{2.5}$ OC measurements made at Bakersfield are described in Liu et al. (2012).

\section{Results and discussion}

The results and discussion are organized such that the contemporary and fossil components of $\mathrm{PM}_{2.5}$ carbon at the Pasadena and Bakersfield sites are discussed, followed by model performance for $\mathrm{PM}_{2.5}$ carbon, speciated VOC, and SOC tracer groups. Table 2 shows episode-aggregated model performance metrics for $\mathrm{PM}_{2.5}$ organic and elemental carbon, SOC tracers, total VOC, and select VOC species. The results of a sensitivity increasing semivolatile yields are presented throughout and discussed in detail before finally providing an evaluation of $\mathrm{PM}_{2.5}$ carbon at all routine monitor sites in California.

\subsection{Contemporary and fossil origins of $\mathbf{P M}_{2.5}$ carbon}

Field campaign average total $\mathrm{PM}_{2.5}$ carbon measurements indicate nearly equal amounts of contemporary and fossil contribution at Pasadena and Bakersfield. The field study average contemporary fraction of $23 \mathrm{~h}$ average $\mathrm{PM}_{2.5}$ total carbon samples is 0.51 at Bakersfield $(N=35)$ and 0.48 at Pasadena $(N=25)$. The estimate for contemporary carbon fraction at Pasadena is consistent with other ${ }^{14} \mathrm{C}$ measurements at this location for this period (Zotter et al., 2014) and similar to measurements made at urban areas in the southeast USA: $52 \%$ contemporary carbon in Birmingham and $63 \%$ in Atlanta (Kleindienst et al., 2010).

Figure 2 shows observed daily $23 \mathrm{~h} \mathrm{PM}_{2.5}$ OC shaded by contemporary and fossil component as well as $\mathrm{PM}_{2.5}$ elemental carbon. The fractional contribution of contemporary carbon to total $\mathrm{PM}_{2.5}$ carbon is variable from day-to-day at the Pasadena site and steadily increases through the study period at the Bakersfield location (first week average of 0.44 and final week average of 0.58 ). Some of the contemporary 
Table 2. Episode average measured and modeled $\mathrm{PM}_{2.5}$ carbon, $\mathrm{PM}_{2.5} \mathrm{SOC}$ groups, and VOC at the Pasadena and Bakersfield sites.

\begin{tabular}{|c|c|c|c|c|c|c|c|c|c|c|}
\hline Species & $\begin{array}{l}\text { Model } \\
\text { run }\end{array}$ & Location & $N$ & $\begin{array}{r}\text { Observed } \\
\left(\mu \mathrm{gC} \mathrm{m}{ }^{-3}\right)\end{array}$ & $\begin{array}{r}\text { Predicted } \\
\left(\mu \mathrm{gC} \mathrm{m}{ }^{-3}\right)\end{array}$ & $\begin{array}{r}\text { Bias } \\
\left(\mu \mathrm{gC} \mathrm{m}^{-3}\right)\end{array}$ & $\begin{array}{r}\text { Error } \\
\left(\mu \mathrm{gC} \mathrm{m}{ }^{-3}\right)\end{array}$ & $\begin{array}{r}\text { Fractional } \\
\text { bias (\%) }\end{array}$ & $\begin{array}{r}\text { Fractional } \\
\text { error }(\%)\end{array}$ & $r$ \\
\hline \multirow[t]{3}{*}{ Elemental carbon } & Baseline & Bakersfield & 35 & 0.5 & 0.4 & -0.1 & 0.1 & -13 & 35 & 0.17 \\
\hline & Baseline & Pasadena & 31 & 0.2 & 1.0 & 0.8 & 0.8 & 125 & 125 & 0.70 \\
\hline & Baseline & CSN/IMPROVE sites & 220 & 0.2 & 0.6 & 0.6 & 0.6 & 77 & 87 & 0.47 \\
\hline \multirow[t]{4}{*}{ Organic carbon } & Baseline & Bakersfield & 35 & 5.4 & 0.8 & -4.6 & 4.6 & -144 & 144 & 0.11 \\
\hline & Baseline & Pasadena & 31 & 3.6 & 2.0 & -1.6 & 1.6 & -53 & 53 & 0.73 \\
\hline & Baseline & CSN/IMPROVE sites & 220 & 1.9 & 1.3 & -0.6 & 0.9 & -34 & 53 & 0.06 \\
\hline & Sensitivity & CSN/IMPROVE sites & 220 & 1.9 & 1.7 & -0.2 & 0.8 & -11 & 42 & 0.32 \\
\hline Species & $\begin{array}{l}\text { Model } \\
\text { run }\end{array}$ & Location & $N$ & $\begin{array}{r}\text { Observed } \\
\left(\mathrm{ngC} \mathrm{m}^{-3}\right)\end{array}$ & $\begin{array}{r}\text { Predicted } \\
\left(\mathrm{ngC} \mathrm{m}^{-3}\right)\end{array}$ & $\begin{array}{r}\text { Bias } \\
\left(\mathrm{ngC} \mathrm{m}^{-3}\right)\end{array}$ & $\begin{array}{r}\text { Error } \\
\left(\mathrm{ngC} \mathrm{m}^{-3}\right)\end{array}$ & $\begin{array}{r}\text { Fractional } \\
\text { bias (\%) }\end{array}$ & $\begin{array}{r}\text { Fractional } \\
\text { error (\%) }\end{array}$ & $r$ \\
\hline \multirow[t]{2}{*}{ Isoprene SOC } & Baseline & Bakersfield & 36 & 96 & 21 & -75 & 75 & -126 & 128 & 0.36 \\
\hline & & Pasadena & 32 & 42 & 27 & -15 & 25 & -60 & 83 & 0.10 \\
\hline \multirow[t]{2}{*}{ Monoterpene SOC } & Baseline & Bakersfield & 35 & 56 & 21 & -35 & 37 & -75 & 89 & 0.66 \\
\hline & & Pasadena & 32 & 82 & 21 & -60 & 61 & -89 & 93 & 0.55 \\
\hline \multirow[t]{2}{*}{ Toluene + xylene SOC } & Baseline & Bakersfield & 35 & 59 & 15 & -44 & 44 & -114 & 114 & 0.62 \\
\hline & & Pasadena & 32 & 125 & 36 & -89 & 89 & -100 & 100 & 0.82 \\
\hline \multirow[t]{2}{*}{ Sesquiterpene SOC } & Baseline & Bakersfield & 41 & & 17 & & & & & \\
\hline & & Pasadena & 41 & & 7 & & & & & \\
\hline \multirow[t]{2}{*}{ Benzene SOC } & Baseline & Bakersfield & 41 & & 2 & & & & & \\
\hline & & Pasadena & 41 & & 2 & & & & & \\
\hline \multirow[t]{2}{*}{ Alkane SOC } & Baseline & Bakersfield & 41 & & 12 & & & & & \\
\hline & & Pasadena & 41 & & 22 & & & & & \\
\hline \multirow[t]{2}{*}{ Cloud SOC } & Baseline & Bakersfield & 41 & & 1 & & & & & \\
\hline & & Pasadena & 41 & & 5 & & & & & \\
\hline \multirow[t]{2}{*}{ Naphthalene SOC } & Baseline & Bakersfield & 36 & 43 & & & & & & \\
\hline & & Pasadena & 32 & 114 & & & & & & \\
\hline Species & $\begin{array}{l}\text { Model } \\
\text { run }\end{array}$ & Location & $N$ & $\begin{array}{r}\text { Observed } \\
(\mathrm{ppbC})\end{array}$ & $\begin{array}{r}\text { Predicted } \\
(\mathrm{ppbC})\end{array}$ & $\begin{array}{r}\text { Bias } \\
(\mathrm{ppbC})\end{array}$ & $\begin{array}{r}\text { Error } \\
(\mathrm{ppbC})\end{array}$ & $\begin{array}{r}\text { Fractional } \\
\text { bias (\%) }\end{array}$ & $\begin{array}{r}\text { Fractional } \\
\text { error }(\%)\end{array}$ & $r$ \\
\hline \multirow[t]{2}{*}{ Isoprene VOC $3 \mathrm{~h}$} & Baseline & Bakersfield & 5 & 0.1 & 0.3 & 0.2 & 0.2 & 79 & 79 & 0.79 \\
\hline & & Pasadena & 8 & 0.6 & 0.5 & -0.2 & 0.5 & 0 & 84 & -0.21 \\
\hline \multirow[t]{2}{*}{ Monoterpene VOC $3 \mathrm{~h}$} & Baseline & Bakersfield & 37 & 1.4 & 0.5 & -0.9 & 1.0 & -72 & 89 & 0.25 \\
\hline & & Pasadena & 28 & 1.8 & 0.3 & -1.5 & 1.6 & -129 & 137 & 0.15 \\
\hline \multirow[t]{2}{*}{ Toluene VOC $3 \mathrm{~h}$} & Baseline & Bakersfield & 41 & 4.3 & 2.7 & -1.6 & 1.9 & -48 & 55 & 0.44 \\
\hline & & Pasadena & 29 & 7.3 & 7.7 & 0.4 & 3.5 & 17 & 44 & 0.24 \\
\hline \multirow[t]{2}{*}{ Xylene VOC $3 \mathrm{~h}$} & Baseline & Bakersfield & 41 & 4.3 & 1.8 & -2.5 & 2.5 & -82 & 83 & 0.34 \\
\hline & & Pasadena & 29 & 6.7 & 4.5 & -2.1 & 2.6 & -33 & 41 & 0.20 \\
\hline \multirow[t]{2}{*}{ Benzene VOC $3 \mathrm{~h}$} & Baseline & Bakersfield & 41 & 1.2 & 1.3 & 0.2 & 0.5 & 6 & 38 & 0.14 \\
\hline & & Pasadena & 29 & 1.5 & 1.6 & 0.1 & 0.5 & 0 & 30 & 0.16 \\
\hline \multirow[t]{2}{*}{ Total VOC $3 \mathrm{~h}$} & Baseline & Bakersfield & 41 & 186.9 & 63.7 & -123.2 & 124.2 & -95 & 97 & 0.37 \\
\hline & & Pasadena & 29 & 188.9 & 88.7 & -100.1 & 100.1 & -66 & 66 & 0.26 \\
\hline \multirow[t]{2}{*}{ Isoprene VOC $1 \mathrm{~h}$} & Baseline & Bakersfield & 712 & 0.4 & 0.4 & 0.0 & 0.3 & -21 & 83 & 0.15 \\
\hline & & Pasadena & 718 & 1.6 & 0.8 & -0.9 & 1.7 & -32 & 139 & -0.10 \\
\hline \multirow[t]{2}{*}{ Monoterpene VOC $1 \mathrm{~h}$} & Baseline & Bakersfield & 605 & 0.8 & 0.3 & -0.6 & 0.7 & -63 & 101 & 0.25 \\
\hline & & Pasadena & 707 & 0.7 & 0.2 & -0.5 & 0.5 & -105 & 111 & 0.05 \\
\hline \multirow[t]{2}{*}{ Toluene VOC $1 \mathrm{~h}$} & Baseline & Bakersfield & 737 & 2.5 & 1.7 & -0.8 & 1.5 & -25 & 56 & 0.31 \\
\hline & & Pasadena & 717 & 4.0 & 6.1 & 2.0 & 2.8 & 36 & 54 & 0.23 \\
\hline \multirow[t]{2}{*}{ Xylene VOC $1 \mathrm{~h}$} & Baseline & Bakersfield & 737 & 1.9 & 1.1 & -0.7 & 1.2 & -37 & 64 & 0.32 \\
\hline & & Pasadena & 718 & 3.2 & 3.4 & 0.2 & 1.7 & 2 & 51 & 0.15 \\
\hline
\end{tabular}

carbon fraction measurements from Pasadena were above 1.0. These samples were considered erroneous and not included in the analysis and suggest the possibility of positive biases due to nearby sources (e.g., medical incinerator) in the area. It is possible some of the stronger day-to-day variability in contemporary carbon fraction measurements at Pasadena may be related to biases due to nearby "hot" sources. Higher time resolution ${ }^{14} \mathrm{C}$ measurements at Pasadena show an increase in fossil fraction during the middle of the day related to increased emissions of fossil $\mathrm{PM}_{2.5}$ carbon precursors and SOA formation in the Los Angeles area (Zotter et al., 2014).
$\mathrm{PM}_{2.5} \mathrm{OC}$ of fossil origin at Pasadena shows the strongest relationship to daily average temperature (Fig. S4a) compared with contemporary carbon, total carbon, and elemental carbon. At Bakersfield the relationship between daily average temperature and fossil and contemporary carbon is similar (Fig. S4b) and not as strong as the relationship in Pasadena. Neither fossil nor contemporary carbon concentrations show discernible patterns by day of the week at either location (Fig. S5).

Modeled contemporary $\mathrm{PM}_{2.5}$ carbon is estimated by summing primarily emitted $\mathrm{PM}_{2.5}$ multiplied by the contempo- 

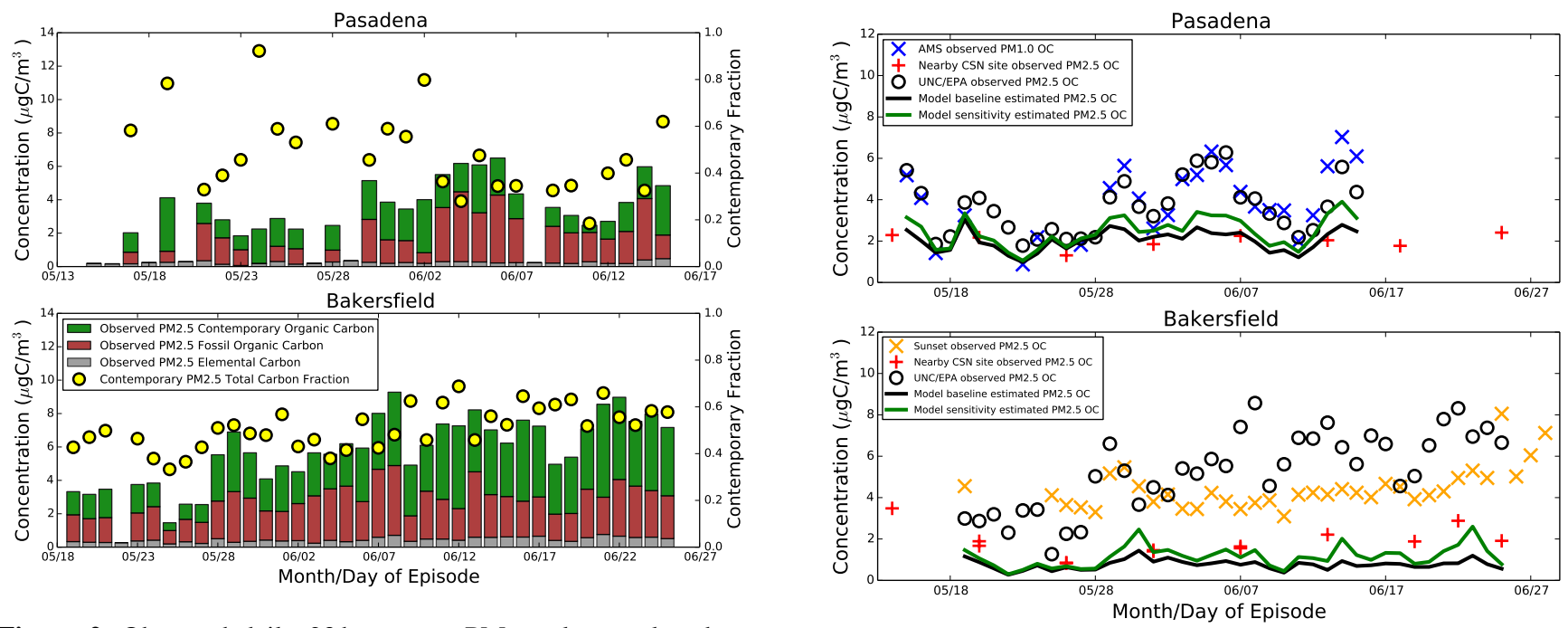

Figure 2. Observed daily $23 \mathrm{~h}$ average $\mathrm{PM}_{2.5}$ elemental carbon, $\mathrm{PM}_{2.5}$ contemporary-origin organic carbon, and $\mathrm{PM}_{2.5}$ fossil-origin organic carbon at Pasadena and Bakersfield.

rary fraction of urban area emissions (see Sect. 2.1 and Table 1) with model-estimated biogenic SOC species. The average baseline modeled contemporary fraction of $\mathrm{PM}_{2.5} \mathrm{OC}$ in Pasadena is 0.51 and Bakersfield 0.54, both of which are similar to average observation estimates. However, the model shows little day-to-day variability in contemporary carbon fraction, which does not match observed trends (Fig. S6). Episode average modeled estimates of $\mathrm{PM}_{2.5}$ OC contemporary fraction are similar to the estimated contemporary fraction of the urban emissions of primary $\mathrm{PM}_{2.5}$ OC (Bakersfield $=0.53$ and Pasadena $=0.51$ ), as noted in Table 1 .

\subsection{PM $_{2.5}$ carbon}

Figure 3 shows measured (UNC/EPA data) and modeled $\mathrm{PM}_{2.5} \mathrm{OC}$ at Bakersfield and Pasadena. Organic carbon measurements from co-located instruments (AMS at Pasadena measured $\mathrm{PM}_{1}$ and Sunset at Bakersfield measured $\mathrm{PM}_{2.5}$ ) and the nearest CSN monitor are also shown in Fig. 3. The co-located AMS measurements compare well with the UNC/EPA PM 2.5 organic carbon measurements at Pasadena, while the concentrations measured at the nearby CSN site are substantially lower. At Bakersfield, UNC/EPA measurements are higher compared with the nearby CSN (episode average $\sim 3$ times higher), and co-located daily average Sunset (episode average $20 \%$ higher) measured $\mathrm{PM}_{2.5}$ OC illustrate possible measurement artifacts in the UNC/EPA measurements at this location. These differences in measured concentration at Bakersfield may be related to filter handling, variability in collected blanks, true differences in the OC concentrations since the CSN site is spatially distinct, differences in the height of measurement (these CSN monitors are situated on top of buildings), and differences in analytical methods since CSN sites use TOR to operationally define OC and EC.

Figure 3. Model-predicted and measured $\mathrm{PM}_{2.5}$ organic carbon at Pasadena and Bakersfield. The nearby CSN measurements are intended to provide additional context and are not co-located with CalNex measurements or model estimates.

Modeled $\mathrm{PM}_{2.5}$ OC is underestimated at both CalNex locations (Fig. 3), most notably at Bakersfield. However, given the large differences in $\mathrm{PM}_{2.5}$ OC mass compared to co-located and nearby routine measurements, it is not clear which measurement best represents ambient $\mathrm{PM}_{2.5}$ OC concentrations and would be most appropriate for comparison with the model. The model generally compares well to the CSN site nearest Pasadena and Bakersfield. $\mathrm{PM}_{2.5}$ elemental carbon is well characterized by the model at Bakersfield (fractional bias $=-13 \%$ and fractional error $=35 \%$ ) and overestimated at Pasadena (fractional bias and error $=125 \%)($ Fig. S7). Since the emissions are based on TOR and UNC/EPA measurements use the TOT operational definition of total carbon, some of the model overestimation may be related to the TOR method estimating higher elemental carbon fraction of total carbon (Chow et al., 2001).

$\mathrm{PM}_{2.5}$ OC is mostly primary (Pasadena $93 \%$ and Bakersfield $88 \%$ ) in the baseline model simulation. AMS measurements at Pasadena suggest OC is mostly secondary in nature with an average of $63 \%$ for the semi-volatile oxidized organic aerosol and oxygenated organic aerosol components for this field study (Hayes et al., 2013). Model-estimated $\mathrm{PM}_{2.5}$ OC is largely from primarily emitted sources and contemporary in nature based on the contemporary/fossil split of primary $\mathrm{PM}_{2.5}$ emissions near both sites (Fig. S6). Primarily emitted $\mathrm{PM}_{2.5} \mathrm{OC}$ emissions sources near Pasadena and Bakersfield include mobile sources, cooking, and dust based on emissions inventory information (Table 1). Some of these sources of primarily emitted $\mathrm{PM}_{2.5}$ OC may be semivolatile in nature. Model treatment of POA as semivolatile may improve the primary-secondary comparison with observations but would likely exacerbate underpredictions of $\mathrm{PM}_{2.5}$ OC 

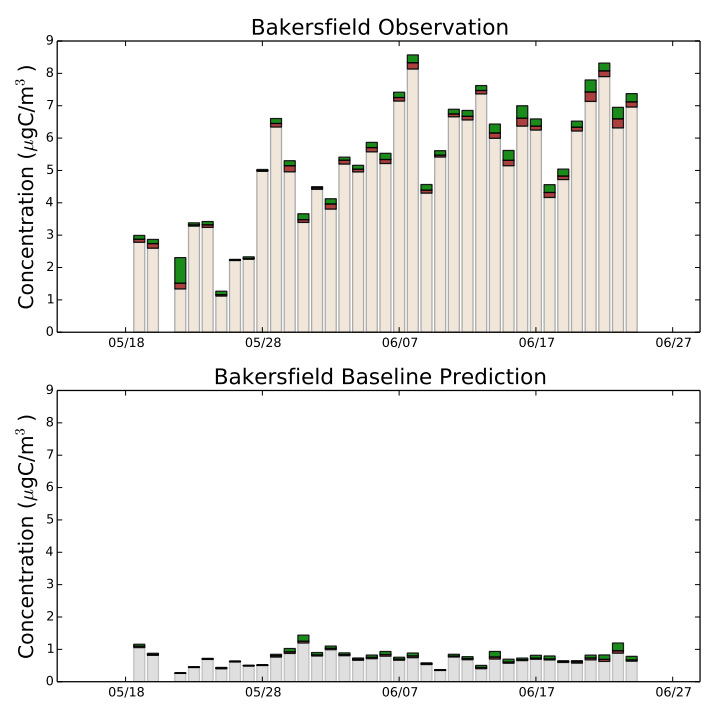

Bakersfield Sensivity Prediction

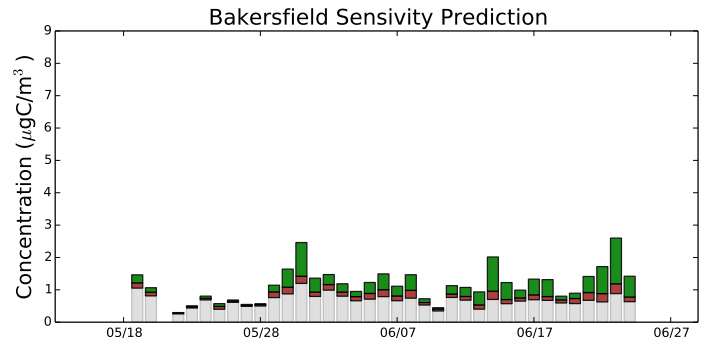

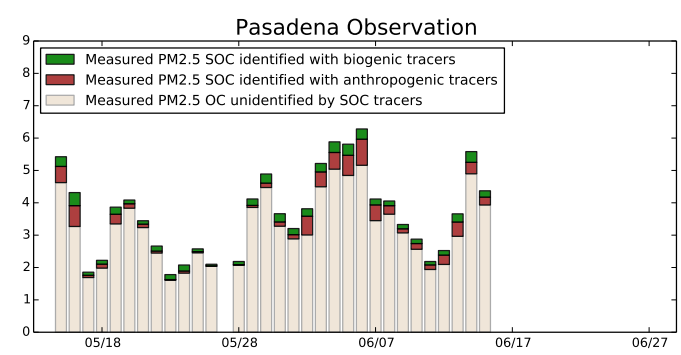
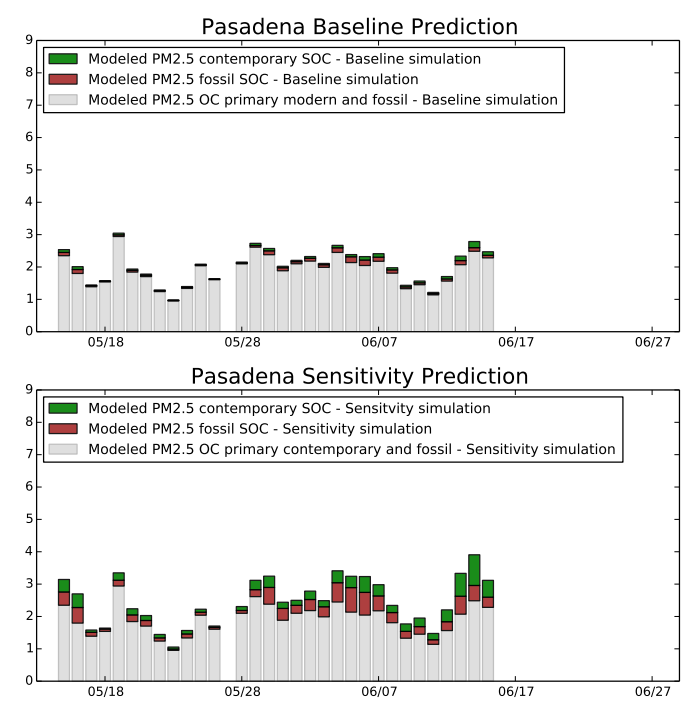

Figure 4. Observed (top row) and modeled (middle and bottom rows) $\mathrm{PM}_{2.5}$ organic carbon at Pasadena and Bakersfield. Mass explained by SOA tracers shown in green (contemporary-origin tracers) and brown (fossil-origin tracers). Top row tan shading indicates mass not explained by known observed SOC tracers. Middle and bottom row gray shading shows modeled primarily emitted $\mathrm{PM}_{2.5}$ that is both contemporary and fossil in origin. Middle row shows baseline model estimates and bottom row model sensitivity results with increased SOA yields.

unless oxidation and re-partitioning of the products is considered (Robinson et al., 2007). The underestimation of SOC may result from underestimated precursor VOC, poorly characterized oxidants, underestimated semivolatile yields, missing intermediate volatility VOC emissions (Stroud et al., 2014; Zhao et al., 2014), other issues, or some combination of each.

\subsection{Gas-phase carbon}

Model estimates are paired with hourly VOCs (Fig. S8) and mid-morning $3 \mathrm{~h}$ average VOC (Fig. S9) at both locations. Compounds considered largely fossil in origin including xylene, toluene, and benzene are generally well predicted at both sites although these species tend to be slightly overestimated at Pasadena and slightly underestimated at Bakersfield. Since emissions of these compounds near these sites are largely from mobile sources (Table 1), this suggests emissions from this sector are fairly well characterized in this application.

Contemporary (biogenic)-origin monoterpenes are underestimated at both sites while isoprene is underestimated at Pasadena and has little bias at Bakersfield based on hourly measurements (Fig. S8; Table 2). Isoprene and monoterpene performance may be partly related to the model not fully capturing transport from nearby areas with large emitting vegetation to these monitor locations (Heo et al., 2015), deficiencies in emissions factors, or poorly characterized vegetation. Speciated monoterpene measurements made at Bakersfield during this field campaign suggest emissions of certain species were elevated at the start of this time period due to flowering (Gentner et al., 2014b), which is a process not included in current biogenic emissions models and thus may contribute to modeled monoterpene underestimates.

Other VOC species that are systematically underestimated include ethane, methanol, ethanol, and acetaldehyde. Underprediction of methanol and ethanol in Bakersfield may be largely related to missing VOC emissions for confined animal operations in the emission inventory (Gentner et al., 2014a). Underestimates of oxygenated VOC compounds may indirectly impact SOC formation through muted photochemistry (Steiner et al., 2008). Carbon monoxide tends to be underestimated at both locations (Fig. S8) possibly due to boundary inflow concentrations from the global model simulation being too low or underestimated regional emissions. 

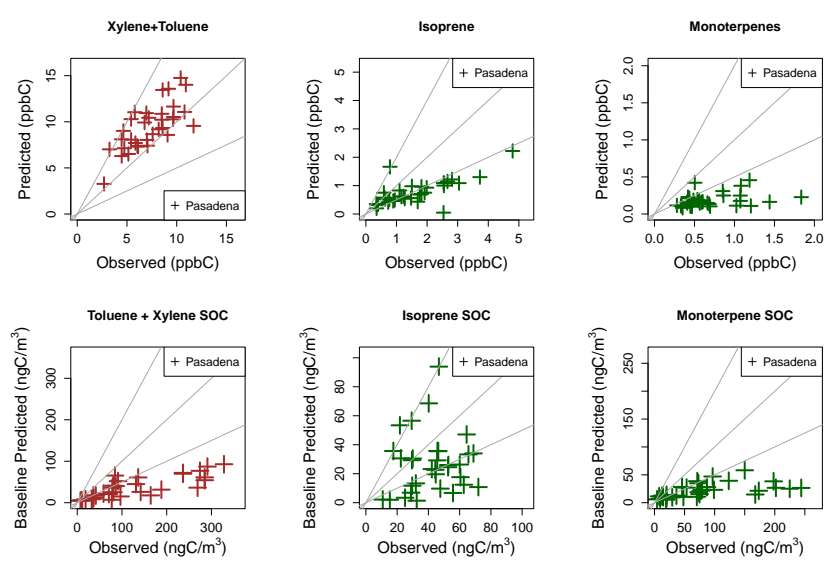

Figure 5. Comparison of CMAQ-predicted and measured VOC (daily average of hourly samples) and corresponding SOC species (daily $23 \mathrm{~h}$ average samples) for Pasadena. Comparison points outside the gray lines indicate model predictions are greater than a factor of 2 different from the measurements.

\subsection{PM $_{2.5}$ SOC tracers}

Figure 4 shows modeled and measured total $\mathrm{PM}_{2.5}$ OC mass. Measured mass explained by fossil and contemporary SOC tracers are shown in the top row. The unexplained observed fraction is a mixture of primary, secondary, fossil, and contemporary origin. Modeled mass is colored to differentiate primarily emitted OC and SOC. Estimates of SOC mass from a specific or lumped VOC group (e.g., isoprene, monoterpenes, toluene), hereafter called SOC tracer mass, comprise little of the measured or modeled $\mathrm{PM}_{2.5}$ OC at either of these locations during this field study (Fig. 4). Total SOC tracer estimates explain only $9 \%$ of the total measured UNC/EPA $\mathrm{PM}_{2.5} \mathrm{OC}$ at Pasadena and $5 \%$ at Bakersfield. The percentage of mass explained by known secondary tracers is smaller than urban areas in the southeast USA: $27 \%$ in Atlanta and $31 \%$ in Birmingham (Kleindienst et al., 2010).

The portion of measured and modeled $\mathrm{PM}_{2.5}$ carbon not identified with tracers may be from underestimated adjustment factors related to previously uncharacterized semivolatile VOC (SVOC) wall loss in chamber studies (Zhang et al., 2014b) and unidentified SOC pathways. Additional reasons for the low estimate of observed tracer contribution to $\mathrm{PM}_{2.5}$ carbon include known pathways without an ambient tracer and tracer degradation between formation and measurement. Based on ${ }^{14} \mathrm{C}$ measurements, this unidentified portion of the measurements is likely comprised of both contemporary and fossil carbon in generally similar amounts. Total modeled SOC explains only $12 \%$ of the $\mathrm{PM}_{2.5}$ carbon at Bakersfield and $7 \%$ at Pasadena. As noted previously, AMS-based observations suggest most OC is SOC (63\%) at Pasadena (Hayes et al., 2013), meaning both the SOC tracer measurements and model estimates explain little of the SOC at this location.
Despite the relatively small component of $\mathrm{PM}_{2.5}$ carbon explained by SOC tracers, a comparison of measured and modeled SOC and precursor VOC provides additional opportunity to better understand sources of $\mathrm{PM}_{2.5}$ carbon in these areas and begin to establish relationships between precursors and resulting SOC formation. Ambient and modelestimated SOC tracers and daily average VOC precursors are shown in Fig. 5 for Pasadena and Fig. 6 for Bakersfield. The model underestimates toluene and xylene SOC at both locations even though VOC gas precursors show an overprediction tendency at Pasadena and only a slight underestimation at Bakersfield. Isoprene SOC is generally underpredicted at both sites, in particular at Bakersfield. This is in contrast to the slight overprediction of daily $24 \mathrm{~h}$ average isoprene at Bakersfield. One explanation may be that isoprene SOC is formed elsewhere in the region (e.g., the nearby foothills of the Sierra Nevada where emissions are highest in the region), which would support the lack of relationship between isoprene SOC and isoprene concentrations at Bakersfield (Heo et al., 2015; Shilling et al., 2013). The lack of relationship could also be related to the reactive uptake kinetics of isoprene-derived epoxydiols (IEPOX) (Gaston et al., 2014) and methacrylic acid epoxide (MAE). Since the model does not include the reactive uptake of IEPOX and MAE and subsequent acid-catalyzed aqueous-phase chemistry, it is likely isoprene SOC would be underestimated to some degree at both sites (Karambelas et al., 2013; Pye et al., 2013). Of these channels the IEPOX channel is thought to have the largest SOA production potential, but the chemistry in the LA basin is dominated by the high-NO channel (Hayes et al., 2014) and thus IEPOX is not formed from isoprene emitted within the LA basin. Consistent with that observation, the AMS tracer of IEPOX SOA is only detected at background level in the LA basin.

Monoterpene VOC and monoterpene SOC are underestimated systematically at both locations, suggesting underpredictions of the VOC precursor translates to underestimates in SOC. As noted previously, monoterpene measurements suggest an emissions enhancement related to flowering or other emission events (e.g., harvest or pruning) (Gentner et al., 2014b) that is not included in current biogenic emissions model formulations. The monoterpene-measured tracer SOC group is based on $\alpha$-pinene products. Measured SOC at these sites could be from monoterpene species other than $\alpha$-pinene. A coincident study near Bakersfield indicates $\alpha$ and $\beta$-pinene emissions represent a fairly small fraction of total monoterpene emissions during this time period (Gentner et al., 2014b). SOA yields in CMAQ for monoterpenes are heavily weighted toward $\alpha$ - and $\beta$-pinene, which may be appropriate in most places but not here where measurements show large contributions from limonene, myrcene, and paracymene. This is important because yields vary among from different monoterpenes and limonene has a much larger SOA yield than pinenes (Carlton et al., 2010). 

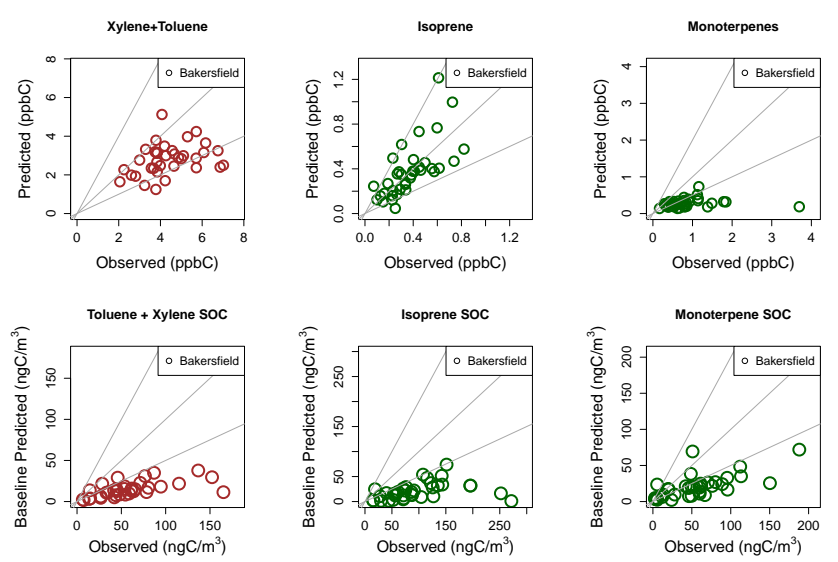

Figure 6. Comparison of CMAQ-predicted and measured VOC (daily average of hourly samples) and corresponding SOC species (daily $23 \mathrm{~h}$ average samples) for Bakersfield. Comparison points outside the gray lines indicate model predictions are greater than a factor of 2 different from the measurements.

Sesquiterpene VOC and SOC tracer $(\beta$-caryophyllenic acid) mass measurements were never above the MDL at either site during CalNex, but the modeling system often predicts SOC from this VOC group (Table 2, Fig. S10b). The SOC tracer measurement methodology is more uncertain for sesquiterpene products (Offenberg et al., 2009) and gasphase sesquiterpenes would have oxidized before reaching the measurement sites since sesquiterpene-emitting vegetation exists in the San Joaquin Valley (Ormeño et al., 2010). It is also possible that SOC is forming from sesquiterpenes other than $\beta$-caryophyllene.

One potential explanation for an underestimation of SOC despite well-characterized precursors (e.g., toluene and xylenes) could be the lack of available oxidants. As shown in Fig. 7, the model tends to overestimate the hydroxyl radical compared with measurement estimates at Pasadena. Hydroperoxyl + peroxy radical measurements are underestimated at Pasadena by a factor of 2 on average. The model overestimates preliminary measurements of both hydroxyl (by nearly a factor of 2 on average) and hydroperoxyl + peroxy radicals at Bakersfield. Model representation of hydroxyl radical at these locations during this time period does not seem to be limiting VOC oxidation to semivolatile products. Better agreement between radical ambient and modeled estimates could result in less SOC produced by the model and exacerbate model SOC underestimates. This suggests deficiencies other than radical representation by the modeling system are more influential in SOC performance for these areas. However, hydroperoxyl underestimates at Pasadena could lead to muted SOA formation through low$\mathrm{NO}_{x}$ pathways dependent on hydroperoxyl concentrations and contribute to model underestimates of SOC.

\subsection{Sensitivity simulation}

$\mathrm{OH}$ is not underestimated in the model and biases in precursor VOC do not clearly translate into similar biases in SOC (e.g., toluene and xylene VOC are overestimated at Pasadena but tracer SOC for this group is underestimated) for these sites during this time period. Modeled SOC may partly be underestimated due to the use of experimental SOC yields that may be biased low due to chamber studies not fully accounting for SVOC wall loss (Zhang et al., 2014b). Even though Zhang et al. (2014b) showed results for one precursor to SOA pathway, for a sensitivity study here the yield of all semivolatile gases is increased by a factor of 4 . This was done by increasing the mass-based stoichiometric coefficients for each VOC-to-SOA pathway in the model to provide a preliminary indication about how increased yields might impact model performance. A factor of 4 is chosen based on the upper limit related to SVOC wall loss in Zhang et al. (2014b). Aside from wall loss characterization, there are a variety of other aspects of chamber studies that could result in underestimated yields including particle-phase accretion, aqueousphase chemistry, and differences in chamber and ambient humidity.

Model estimates of $\mathrm{PM}_{2.5} \mathrm{OC}$ increase in urban areas and regionally when semivolatile yields are increased. The sensitivity simulation results in episode average anthropogenic SOC increases between a factor of 3 (benzene SOC at Pasadena) to 4.8 (toluene and xylene SOC at Pasadena) and biogenic SOC increases between a factor of 5.1 (isoprene SOC at Pasadena) to 8.9 (monoterpene SOC at Bakersfield). Model performance improves at the CalNex locations (Figs. 3 and 4) and at routine monitors throughout California (Fig. 8). Average fractional bias improves from -34 to $-11 \%$ at routine monitor locations and fractional error is reduced from 53 to $42 \%$.

The sensitivity simulation with increased semivolatile yields results in increased model-estimated secondary contribution as a percent of $\mathrm{PM}_{2.5}$ carbon but still does not conform to observation-based estimates that indicate $\mathrm{PM}_{2.5}$ carbon is largely secondary in nature at these sites (Liu et al., 2012; Hayes et al., 2013). Modeled SOC in the sensitivity simulation explains $36 \%$ of the $\mathrm{PM}_{2.5} \mathrm{OC}$ at Bakersfield and $22 \%$ at Pasadena, which is larger than the baseline simulation by more than a factor of 3 . The model-predicted percent contemporary fraction of $\mathrm{PM}_{2.5}$ carbon changed very little due to this sensitivity. The model sensitivity results are not compared to SOC tracer group estimates since the conversion of tracer concentrations to SOC concentrations would require a similar adjustment and would result in similar relationships between model estimates and observations.

\subsection{Aqueous and other SOC processes}

Measurements in Pasadena during the summer of 2009 suggest aqueous processes can be important for SOC mass 
$\mathrm{OH}$ - Pasadena

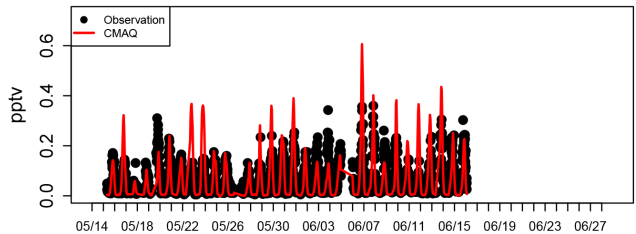

HO2+RO2 - Pasadena

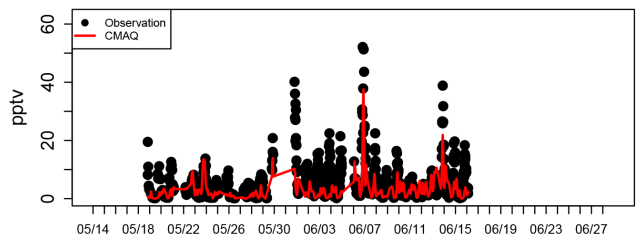

$\mathrm{OH}$ - Pasadena

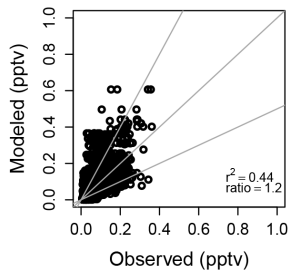

HO2+RO2 - Pasaden

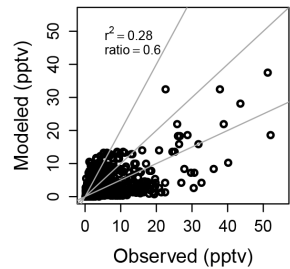

Figure 7. Measured and model-estimated $\mathrm{OH}$ radical (top) and $\mathrm{HO}_{2}+\mathrm{RO}_{2}$ (bottom) at Pasadena. The ratio shown on the scatterplots is the episode average model estimate divided by the episode average measured values.
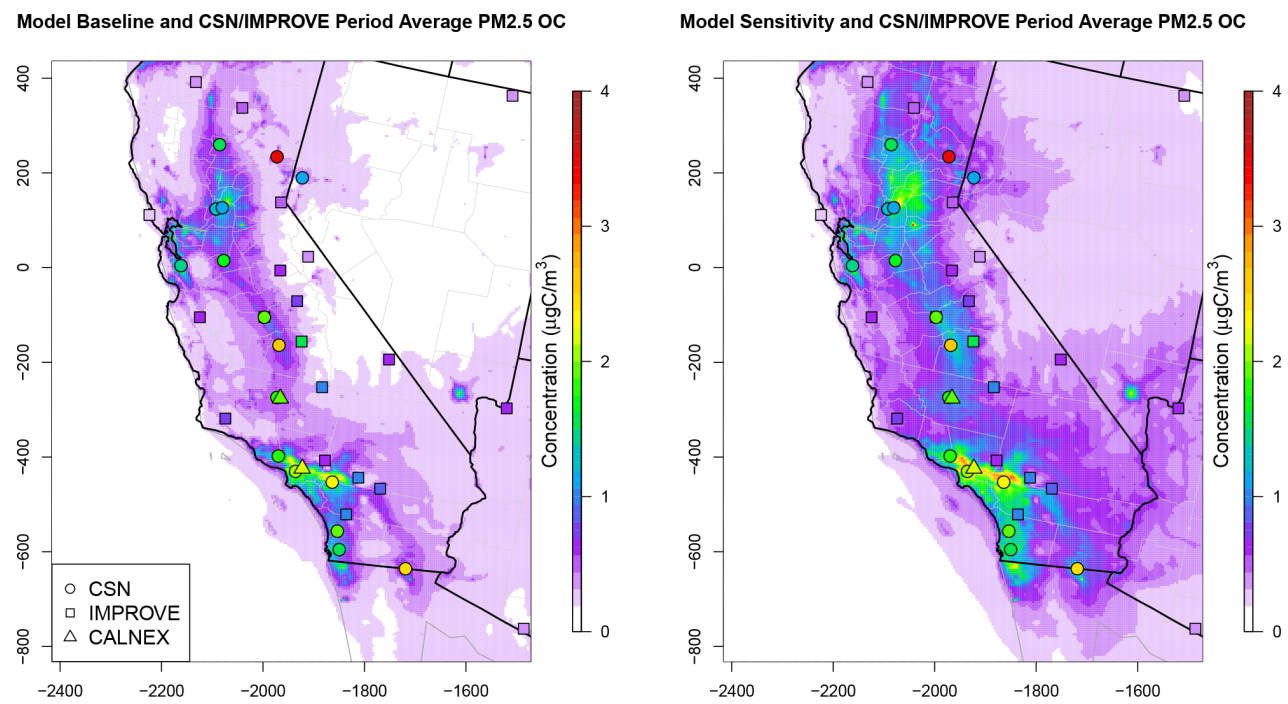

Figure 8. Episode average modeled $\mathrm{PM}_{2.5}$ organic carbon and measurements from both CalNex locations and routine networks including CSN (circles) and IMPROVE (squares). Left panel shows baseline model predictions and right panel shows model estimates with increased SOA yields.

(Hersey et al., 2011). For the CalNex period at Pasadena, other research showed box-model-estimated $8 \mathrm{~h}$ average SOC from aqueous-phase chemistry of glyoxal to be between 0.0 and $0.2 \mu \mathrm{g} \mathrm{m}^{-3}$ (Washenfelder et al., 2011), and Hayes et al. (2014) showed that the observed SOA was not different between cloudy and clear morning days. CMAQpredicted $24 \mathrm{~h}$ average SOC from glyoxal and methylglyoxal through aqueous chemistry at Pasadena ranges from 0.0 to $0.04 \mu \mathrm{g} \mathrm{m}^{-3}$. CMAQ estimates of SOC from small carbonyl compounds via aqueous-phase processes are within the range inferred from measurements.
Not all CMAQ SOC formation pathways can be included in this analysis. No observational indicator exists for SOC derived from alkanes, benzene, glyoxal, and methylglyoxal since unique tracer species have not been determined. Conversely, naphthalene/polycyclic aromatic hydrocarbons (PAHs) SOC tracers were measured but not modeled in CMAQ. Measured naphthalene SOC at these sites is minor (Hayes et al., 2014), which is consistent with other areas (Dzepina et al., 2009). Previous CMAQ simulations predict that PAHs contribute less than $30 \mathrm{ng} \mathrm{m}^{-3}$ of SOA in Southern California in summer (Pye and Pouliot, 2012), and thus including those pathways is unlikely to close the 
model-measurement gap in $\mathrm{PM}_{2.5}$ OC. 2-Methyl-3-buten-2ol (MBO) derived SOC concentrations $\left(3-4 \mathrm{ngC} \mathrm{m}^{-3}\right)$ were low at both monitor locations throughout the campaign (Lewandowski et al., 2013). MBO does not appear to notably contribute SOC at these locations during this time period, which is consistent with low yields estimated in laboratory experiments (Chan et al., 2009). Organic carbon emitted from marine biological activity is not included in this modeling assessment and may contribute to some degree at Pasadena (Gantt et al., 2010) based on ship-based measurements (Hayes et al., 2013).

\subsection{Regional $\mathbf{P M}_{2.5}$ organic carbon}

Including routine measurement data is important to provide broader context for $\mathrm{PM}_{2.5}$ carbon in California and understand how the model performs and responds to perturbations at diverse locations beyond the two CalNex sites. The highest average modeled $\mathrm{PM}_{2.5}$ OC in California during this period is in the Los Angeles area (Fig. 8). The Sacramento and San Joaquin valleys also show higher concentrations of $\mathrm{PM}_{2.5}$ OC than more rural parts of the state (Fig. 8). Measurements made at routine monitor networks (Fig. 8) show similar elevated concentrations near Los Angeles, Sacramento Valley, and San Joaquin Valley. These areas of elevated OC generally coincide with areas of the state that experience a build-up of pollutants due to terrain features blocking air flow (Baker et al., 2013). The model does not tend to capture the highest concentrations of measured $\mathrm{PM}_{2.5}$ OC in the central San Joaquin Valley, Imperial Valley, or at one CSN monitor in the northeast Sierra Nevada that is near large residential wood combustion emissions (Fig. S11). The model underestimates $\mathrm{PM}_{2.5}$ OC on average across all CSN sites during this time period (fractional bias $=-34 \%$ and fractional error $=53 \%$ ). The modeling system shows an overprediction tendency (fractional bias $=77 \%$ ) across all CSN sites for $\mathrm{PM}_{2.5}$ elemental carbon in California during this period.

\section{Conclusions}

Total $\mathrm{PM}_{2.5}$ carbon at Pasadena and Bakersfield during the CalNex period in May and June 2010 is fairly evenly split between contemporary and fossil origin. Total $\mathrm{PM}_{2.5}$ OC is generally underestimated at both field study locations and at many routine measurement sites in California, and comparison with AMS observations suggests a large underestimation of SOC. Semivolatile yields were increased by a factor of 4 based on recent research suggesting yields may be higher due to updated accounting for SVOC wall loss. This sensitivity resulted in a better comparison to routine and field study measurements. However, the model-estimated OC is still largely primary in nature and inconsistent with observationbased approaches at these sites. A modeling study for the same time period using different emissions, photochemical transport model, and SOA treatment also shows underestimated OA and SOA at Pasadena and underestimated SOA but comparable OA at the Bakersfield location (Fast et al., 2014).

CMAQ predictions of individual VOCs are often not consistent with model performance for the corresponding subsequent SOC species mass. Gas-phase mixing ratios of toluene and xylene are well predicted by CMAQ, typically within a factor of 2 of the observations at both sites. However, measurement-based estimates of the corresponding SOC mass are consistently greater than model-predicted mass. Mass concentrations of the isoprene SOC are systematically underpredicted, most noticeably at Bakersfield, while model predictions of gas-phase isoprene are not biased in only one direction to the same degree. Gas-phase monoterpenes and the related SOC species are underpredicted at both CalNex monitoring sites. The hydroxyl radical is fairly well characterized at Pasadena and systematically overestimated at Bakersfield, suggesting oxidants are not limiting SOC production in the model.

Episode average CMAQ model estimates of $\mathrm{PM}_{2.5}$ OC contemporary fraction at Pasadena and Bakersfield are similar to radiocarbon measurements but lack day-to-day variability. CMAQ $\mathrm{PM}_{2.5}$ OC is predominantly primary in origin, which is contrary to findings from other studies that indicate $\mathrm{PM}_{2.5} \mathrm{OC}$ in these areas are largely secondary in nature during this time period (Bahreini et al., 2012; Hayes et al., 2013; Liu et al., 2012). Treatment of primarily emitted $\mathrm{PM}_{2.5}$ OC as semivolatile would likely result in total $\mathrm{PM}_{2.5}$ OC estimates that would be mostly secondary rather than primary. However, this would likely exacerbate model underestimates of $\mathrm{PM}_{2.5}$ OC. Some model performance features, including underestimated SOC, may be related to less volatile hydrocarbon emissions missing from the emission inventory (Chan et al., 2013; Gentner et al., 2012; Jathar et al., 2014; Zhao et al., 2014) or mischaracterized when lumped into chemical mechanism VOC species (Jathar et al., 2014). A future intent is to simulate this same period using a volatility basis set approach to treat primary OC emissions with some degree of volatility and potential for SOC production and better account for sector-specific intermediate volatility emissions.

\section{The Supplement related to this article is available online at doi:10.5194/acp-15-5243-2015-supplement.}

Acknowledgements. The authors would like to acknowledge measurements taken by Scott Scheller and the contribution from Chris Misenis, Allan Beidler, Chris Allen, James Beidler, Heather Simon, and Rich Mason. EPA, through its Office of Research and Development, funded and collaborated in the research described here under contract EP-D-10-070 to Alion Science and Technology. This work is supported in part through EPA's STAR 
program, grant number RD83504101. P. L. Hayes and J. L. Jimenez were supported by CARB 11-305.

Disclaimer. Although this work was reviewed by EPA and approved for publication, it may not necessarily reflect official agency policy.

Edited by: R. McLaren

\section{References}

Bahreini, R., Middlebrook, A. M., de Gouw, J. A., Warneke, C., Trainer, M., Brock, C. A., Stark, H., Brown, S. S., Dube, W. P., Gilman, J. B., Hall, K., Holloway, J. S., Kuster, W. C., Perring, A. E., Prevot, A. S. H., Schwarz, J. P., Spackman, J. R., Szidat, S., Wagner, N. L., Weber, R. J., Zotter, P., and Parrish, D. D.: Gasoline emissions dominate over diesel in formation of secondary organic aerosol mass, Geophys. Res. Lett., 39, L06805, doi:10.1029/2011g1050718, 2012.

Baker, K. R., Misenis, C., Obland, M. D., Ferrare, R. A., Scarino, A. J., and Kelly, J. T.: Evaluation of surface and upper air fine scale WRF meteorological modeling of the May and June 2010 CalNex period in California, Atmos. Environ., 80, 299-309, 2013.

Barsanti, K. C., Carlton, A. G., and Chung, S. H.: Analyzing experimental data and model parameters: implications for predictions of SOA using chemical transport models, Atmos. Chem. Phys., 13, 12073-12088, doi:10.5194/acp-13-12073-2013, 2013.

Birch, M. and Cary, R.: Elemental carbon-based method for monitoring occupational exposures to particulate diesel exhaust, Aerosol Sci. Technol., 25, 221-241, 1996.

Borbon, A., Gilman, J., Kuster, W., Grand, N., Chevaillier, S., Colomb, A., Dolgorouky, C., Gros, V., Lopez, M., and SardaEsteve, R.: Emission ratios of anthropogenic volatile organic compounds in northern mid-latitude megacities: Observations versus emission inventories in Los Angeles and Paris, J. Geophys. Res.-Atmos., 118, 2041-2057, 2013.

Carlton, A. G. and Baker, K. R.: Photochemical Modeling of the Ozark Isoprene Volcano: MEGAN, BEIS, and Their Impacts on Air Quality Predictions, Environ. Sci. Technol., 45, 4438-4445, doi:10.1021/es200050x, 2011.

Carlton, A. G., Turpin, B. J., Altieri, K. E., Reff, A., Seitzinger, S., Lim, H. J., and Ervens, B.: Atmospheric Oxalic Acid and SOA Production from Glyoxal: Results of Aqueous Photooxidation Experiments, Atmos. Environ., 41, 7588-7602, 2007.

Carlton, A. G., Turpin, B. J., Altieri, K. E., Seitzinger, S. P., Mathur, R., Roselle, S. J., and Weber, R. J.: CMAQ model performance enhanced when in-cloud SOA is included: comparisons of OC predictions with measurements, Environ. Sci. Technol., 42, 8798-8802, 2008.

Carlton, A. G., Bhave, P. V., Napelenok, S. L., Edney, E. O., Sarwar, G., Pinder, R. W., Pouliot, G. A., and Houyoux, M.: Treatment of secondary organic aerosol in CMAQv4.7, Environ. Sci. Technol., 44, 8553-8560, 2010.

Carter, W. P. L.: Implementation of the SAPRC-99 chemical mechanism into the models-3 framework, U.S. Environmental Protection Agency, University of California, Riverside, CA, USA, 2000 .
Chan, A. W., Isaacman, G., Wilson, K. R., Worton, D. R., Ruehl, C. R., Nah, T., Gentner, D. R., Dallmann, T. R., Kirchstetter, T. W., and Harley, R. A.: Detailed chemical characterization of unresolved complex mixtures in atmospheric organics: Insights into emission sources, atmospheric processing, and secondary organic aerosol formation, J. Geophys. Res.-Atmos., 118, 67836796, 2013.

Chan, A. W. H., Galloway, M. M., Kwan, A. J., Chhabra, P. S., Keutsch, F. N., Wennberg, P. O., Flagan, R. C., and Seinfeld, J. H.: Photooxidation of 2-Methyl-3-Buten-2-ol (MBO) as a Potential Source of Secondary Organic Aerosol, Environ. Sci. Technol., 43, 4647-4652, doi:10.1021/es802560w, 2009.

Chow, J. C., Watson, J. G., Crow, D., Lowenthal, D. H., and Merrifield, T.: Comparison of IMPROVE and NIOSH carbon measurements, Aerosol Sci. Technol., 34, 23-34, 2001.

Chung, S. H. and Seinfeld, J. H.: Global distribution and climate forcing of carbonaceous aerosols, J. Geophys. Res.-Atmos., 107, AAC14.11-AAC14.33, doi:10.1029/2001jd001397, 2002.

Docherty, K. S., Stone, E. A., Ulbrich, I. M., DeCarlo, P. F., Snyder, D. C., Schauer, J. J., Peltier, R. E., Weber, R. J., Murphy, S. N., Seinfeld, J. H., Grover, B. D., Eatough, D. J., and Jiimenez, J. L.: Apportionment of Primary and Secondary Organic Aerosols in Southern California during the 2005 Study of Organic Aerosols in Riverside (SOAR-1), Environ. Sci. Technol., 42, 7655-7662, doi:10.1021/es8008166, 2008.

Dusanter, S., Vimal, D., Stevens, P. S., Volkamer, R., and Molina, L. T.: Measurements of $\mathrm{OH}$ and $\mathrm{HO}_{2}$ concentrations during the MCMA-2006 field campaign - Part 1: Deployment of the Indiana University laser-induced fluorescence instrument, Atmos. Chem. Phys., 9, 1665-1685, doi:10.5194/acp-9-1665-2009, 2009.

Dzepina, K., Volkamer, R. M., Madronich, S., Tulet, P., Ulbrich, I. M., Zhang, Q., Cappa, C. D., Ziemann, P. J., and Jimenez, J. L.: Evaluation of recently-proposed secondary organic aerosol models for a case study in Mexico City, Atmos. Chem. Phys., 9, 5681-5709, doi:10.5194/acp-9-5681-2009, 2009.

Edney, E. O., Kleindienst, T. E., Conver, T. S., McIver, C. D., Corse, E. W., and Weathers, W. S.: Polar organic oxygenates in $\mathrm{PM}_{2.5}$ at a southeastern site in the United States, Atmos. Environ., 37, 3947-3965, 2003.

Ensberg, J. J., Hayes, P. L., Jimenez, J. L., Gilman, J. B., Kuster, W. C., de Gouw, J. A., Holloway, J. S., Gordon, T. D., Jathar, S., Robinson, A. L., and Seinfeld, J. H.: Emission factor ratios, SOA mass yields, and the impact of vehicular emissions on SOA formation, Atmos. Chem. Phys., 14, 2383-2397, doi:10.5194/acp14-2383-2014, 2014.

ENVIRON: User's Guide Comprehensive Air Quality Model with Extensions version 6, available at: www.camx.com (last access: 8 May 2015), ENVIRON International Corporation, Novato, 2014.

Ervens, B., Turpin, B. J., and Weber, R. J.: Secondary organic aerosol formation in cloud droplets and aqueous particles (aqSOA): a review of laboratory, field and model studies, Atmos. Chem. Phys., 11, 11069-11102, doi:10.5194/acp-1111069-2011, 2011.

Fast, J. D., Allan, J., Bahreini, R., Craven, J., Emmons, L., Ferrare, R., Hayes, P. L., Hodzic, A., Holloway, J., Hostetler, C., Jimenez, J. L., Jonsson, H., Liu, S., Liu, Y., Metcalf, A., Middlebrook, A., Nowak, J., Pekour, M., Perring, A., Russell, L., Sedlacek, A., Seinfeld, J., Setyan, A., Shilling, J., Shrivastava, M., Springston, 
S., Song, C., Subramanian, R., Taylor, J. W., Vinoj, V., Yang, Q., Zaveri, R. A., and Zhang, Q.: Modeling regional aerosol and aerosol precursor variability over California and its sensitivity to emissions and long-range transport during the $2010 \mathrm{CalNex}$ and CARES campaigns, Atmos. Chem. Phys., 14, 10013-10060, doi:10.5194/acp-14-10013-2014, 2014.

Fountoukis, C. and Nenes, A.: ISORROPIA II: a computationally efficient thermodynamic equilibrium model for $\mathrm{K}^{+}$. $\mathrm{Ca}^{2+}-\mathrm{Mg}^{2+}-\mathrm{NH}^{4+}-\mathrm{Na}^{+}-\mathrm{SO}_{4}^{2-}-\mathrm{NO}_{3}^{-}-\mathrm{Cl}^{-}-\mathrm{H}_{2} \mathrm{O}$ aerosols, Atmos. Chem. Phys., 7, 4639-4659, doi:10.5194/acp-7-4639-2007, 2007.

Gantt, B., Meskhidze, N., and Carlton, A. G.: The contribution of marine organics to the air quality of the western United States, Atmos. Chem. Phys., 10, 7415-7423, doi:10.5194/acp-10-74152010, 2010.

Gaston, C. J., Riedel, T. P., Zhang, Z., Gold, A., Surratt, J. D., and Thornton, J. A.: Reactive Uptake of an Isoprene-derived Epoxydiol to Submicron Aerosol Particles, Environ. Sci. Technol., 48, 11178-11186, doi:10.1021/es5034266, 2014.

Gentner, D. R., Isaacman, G., Worton, D. R., Chan, A. W. H., Dallmann, T. R., Davis, L., Liu, S., Day, D. A., Russell, L. M., Wilson, K. R., Weber, R., Guha, A., Harley, R. A., and Goldstein, A. H.: Elucidating secondary organic aerosol from diesel and gasoline vehicles through detailed characterization of organic carbon emissions, P. Natl. Acad. Sci. USA, 109, 18318-18323, doi:10.1073/pnas.1212272109, 2012.

Gentner, D. R., Ford, T. B., Guha, A., Boulanger, K., Brioude, J., Angevine, W. M., de Gouw, J. A., Warneke, C., Gilman, J. B., Ryerson, T. B., Peischl, J., Meinardi, S., Blake, D. R., Atlas, E., Lonneman, W. A., Kleindienst, T. E., Beaver, M. R., Clair, J. M. St., Wennberg, P. O., VandenBoer, T. C., Markovic, M. Z., Murphy, J. G., Harley, R. A., and Goldstein, A. H.: Emissions of organic carbon and methane from petroleum and dairy operations in California's San Joaquin Valley, Atmos. Chem. Phys., 14, 4955-4978, doi:10.5194/acp-14-4955-2014, 2014a.

Gentner, D. R., Ormeño, E., Fares, S., Ford, T. B., Weber, R., Park, J.-H., Brioude, J., Angevine, W. M., Karlik, J. F., and Goldstein, A. H.: Emissions of terpenoids, benzenoids, and other biogenic gas-phase organic compounds from agricultural crops and their potential implications for air quality, Atmos. Chem. Phys., 14, 5393-5413, doi:10.5194/acp-14-5393-2014, 2014 b.

Gerbig, C., Schmitgen, S., Kley, D., Volz-Thomas, A., Dewey, K., and Haaks, D.: An improved fast-response vacuum-UV resonance fluorescence CO instrument, J. Geophys. Res.-Atmos., 104, 1699-1704, 1999.

Geron, C.: Carbonaceous aerosol over a Pinus taeda forest in Central North Carolina, USA, Atmos. Environ., 43, 959-969, 2009.

Gilman, J. B., Burkhart, J. F., Lerner, B. M., Williams, E. J., Kuster, W. C., Goldan, P. D., Murphy, P. C., Warneke, C., Fowler, C., Montzka, S. A., Miller, B. R., Miller, L., Oltmans, S. J., Ryerson, T. B., Cooper, O. R., Stohl, A., and de Gouw, J. A.: Ozone variability and halogen oxidation within the Arctic and sub-Arctic springtime boundary layer, Atmos. Chem. Phys., 10, 10223-10236, doi:10.5194/acp-10-10223-2010, 2010.

Grell, G. A., Peckham, S. E., Schmitz, R., McKeen, S. A., Frost, G., Skamarock, W. C., and Eder, B.: Fully coupled "online" chemistry within the WRF model, Atmos. Environ., 39, 6957-6975, doi:10.1016/j.atmosenv.2005.04.027, 2005.
Griffith, S. M., Hansen, R. F., Dusanter, S., Stevens, P. S., Alaghmand, M., Bertman, S. B., Carroll, M. A., Erickson, M., Galloway, M., Grossberg, N., Hottle, J., Hou, J., Jobson, B. T., Kammrath, A., Keutsch, F. N., Lefer, B. L., Mielke, L. H., O'Brien, A., Shepson, P. B., Thurlow, M., Wallace, W., Zhang, N., and Zhou, X. L.: $\mathrm{OH}$ and $\mathrm{HO} 2$ radical chemistry during PROPHET 2008 and CABINEX 2009 - Part 1: Measurements and model comparison, Atmos. Chem. Phys., 13, 5403-5423, doi:10.5194/acp-13-5403-2013, 2013.

Hallquist, M., Wenger, J. C., Baltensperger, U., Rudich, Y., Simpson, D., Claeys, M., Dommen, J., Donahue, N. M., George, C., Goldstein, A. H., Hamilton, J. F., Herrmann, H., Hoffmann, T., Iinuma, Y., Jang, M., Jenkin, M. E., Jimenez, J. L., Kiendler-Scharr, A., Maenhaut, W., McFiggans, G., Mentel, Th. F., Monod, A., Prévôt, A. S. H., Seinfeld, J. H., Surratt, J. D., Szmigielski, R., and Wildt, J.: The formation, properties and impact of secondary organic aerosol: current and emerging issues, Atmos. Chem. Phys., 9, 5155-5236, doi:10.5194/acp-9-51552009, 2009.

Hayes, P. L., Ortega, A. M., Cubison, M. J., Froyd, K. D., Zhao, Y., Cliff, S. S., Hu, W. W., Toohey, D. W., Flynn, J. H., Lefer, B. L., Grossberg, N., Alvarez, S., Rappenglueck, B., Taylor, J. W., Allan, J. D., Holloway, J. S., Gilman, J. B., Kuster, W. C., De Gouw, J. A., Massoli, P., Zhang, X., Liu, J., Weber, R. J., Corrigan, A. L., Russell, L. M., Isaacman, G., Worton, D. R., Kreisberg, N. M., Goldstein, A. H., Thalman, R., Waxman, E. M., Volkamer, R., Lin, Y. H., Surratt, J. D., Kleindienst, T. E., Offenberg, J. H., Dusanter, S., Griffith, S., Stevens, P. S., Brioude, J., Angevine, W. M., and Jimenez, J. L.: Organic aerosol composition and sources in Pasadena, California, during the 2010 CalNex campaign, J. Geophys. Res.-Atmos., 118, 9233-9257, doi:10.1002/jgrd.50530, 2013.

Hayes, P. L., Carlton, A. G., Baker, K. R., Ahmadov, R., Washenfelder, R. A., Alvarez, S., Rappenglück, B., Gilman, J. B., Kuster, W. C., de Gouw, J. A., Zotter, P., Prévôt, A. S. H., Szidat, S., Kleindienst, T. E., Offenberg, J. H., and Jimenez, J. L.: Modeling the formation and aging of secondary organic aerosols in Los Angeles during CalNex 2010, Atmos. Chem. Phys. Discuss., 14, 32325-32391, doi:10.5194/acpd-14-32325-2014, 2014.

Henderson, B. H., Akhtar, F., Pye, H. O. T., Napelenok, S. L., and Hutzell, W. T.: A database and tool for boundary conditions for regional air quality modeling: description and evaluation, Geosci. Model Dev., 7, 339-360, doi:10.5194/gmd-7-3392014, 2014.

Henze, D. K. and Seinfeld, J. H.: Global secondary organic aerosol from isoprene oxidation, Geophys. Res. Lett., 33, L09812, doi:10.1029/2006g1025976, 2006.

Heo, J., de Foy, B., Olson, M. R., Pakbin, P., Sioutas, C., and Schauer, J. J.: Impact of regional transport on the anthropogenic and biogenic secondary organic aerosols in the Los Angeles Basin, Atmos. Environ., 103, 171-179, 2015.

Hersey, S. P., Craven, J. S., Schilling, K. A., Metcalf, A. R., Sorooshian, A., Chan, M. N., Flagan, R. C., and Seinfeld, J. H.: The Pasadena Aerosol Characterization Observatory (PACO): chemical and physical analysis of the Western Los Angeles basin aerosol, Atmos. Chem. Phys., 11, 7417-7443, doi:10.5194/acp11-7417-2011, 2011.

Hutzell, W. T., Luecken, D. J., Appel, K. W., and Carter, W. P. L.: Interpreting predictions from the SAPRC07 mechanism based on 
regional and continental simulations, Atmos. Environ., 46, 417429, doi:10.1016/j.atmosenv.2011.09.030, 2012.

Jathar, S. H., Gordon, T. D., Hennigan, C. J., Pye, H. O. T., Pouliot, G., Adams, P. J., Donahue, N. M., and Robinson, A. L.: Unspeciated organic emissions from combustion sources and their influence on the secondary organic aerosol budget in the United States, P. Natl. Acad. Sci. USA, 111, 10473-10478, doi:10.1073/pnas.1323740111, 2014.

Jimenez, J. L., Canagaratna, M. R., Donahue, N. M., Prevot, A. S. H., Zhang, Q., Kroll, J. H., DeCarlo, P. F., Allan, J. D., Coe, H., Ng, N. L., Aiken, A. C., Docherty, K. S., Ulbrich, I. M., Grieshop, A. P., Robinson, A. L., Duplissy, J., Smith, J. D., Wilson, K. R., Lanz, V. A., Hueglin, C., Sun, Y. L., Tian, J., Laaksonen, A., Raatikainen, T., Rautiainen, J., Vaattovaara, P., Ehn, M., Kulmala, M., Tomlinson, J. M., Collins, D. R., Cubison, M. J., Dunlea, E. J., Huffman, J. A., Onasch, T. B., Alfarra, M. R., Williams, P. I., Bower, K., Kondo, Y., Schneider, J., Drewnick, F., Borrmann, S., Weimer, S., Demerjian, K., Salcedo, D., Cottrell, L., Griffin, R., Takami, A., Miyoshi, T., Hatakeyama, S., Shimono, A., Sun, J. Y., Zhang, Y. M., Dzepina, K., Kimmel, J. R., Sueper, D., Jayne, J. T., Herndon, S. C., Trimborn, A. M., Williams, L. R., Wood, E. C., Middlebrook, A. M., Kolb, C. E., Baltensperger, U., and Worsnop, D. R.: Evolution of Organic Aerosols in the Atmosphere, Science, 326, 1525-1529, doi:10.1126/science.1180353, 2009.

Karambelas, A., Pye, H. O. T., Budisulistiorini, S. H., Surratt, J. D., and Pinder, R. W.: Isoprene epoxydiol contribution to urban organic aerosol: evidence from modeling and measurements, Environ. Sci. Technol. Lett., 1, 278-283, doi:10.1021/ez5001353, 2013.

Kelly, J. T., Baker, K. R., Nowak, J. B., Murphy, J. G., Markovic, M. Z., VandenBoer, T. C., Ellis, R. A., Neuman, J. A., Weber, R. J., and Roberts, J. M.: Fine-scale simulation of ammonium and nitrate over the South Coast Air Basin and San Joaquin Valley of California during CalNex-2010, J. Geophys. Res.-Atmos., 119, 3600-3614, doi:10.1002/2013JD021290, 2014.

Kleindienst, T. E., Conver, T. S., McIver, C. D., and Edney, E. O.: Determination of secondary organic aerosol products from the photooxidation of toluene and their implications in ambient $\mathrm{PM}_{2.5}$, J. Atmos. Chem., 47, 79-100, 2004.

Kleindienst, T. E., Jaoui, M., Lewandowski, M., Offenberg, J. H., Lewis, C. W., Bhave, P. V., and Edney, E. O.: Estimates of the contributions of biogenic and anthropogenic hydrocarbons to secondary organic aerosol at a southeastern US location, Atmos. Environ., 41, 8288-8300, doi:10.1016/j.atmosenv.2007.06.045, 2007.

Kleindienst, T. E., Lewandowski, M., Offenberg, J. H., Edney, E. O., Jaoui, M., Zheng, M., Ding, X. A., and Edgerton, E. S.: Contribution of Primary and Secondary Sources to Organic Aerosol and $\mathrm{PM}_{2.5}$ at SEARCH Network Sites, J. Air Waste Ma., 60, 1388-1399, doi:10.3155/1047-3289.60.11.1388, 2010.

Lewandowski, M., Piletic, I. R., Kleindienst, T. E., Offenberg, J. H., Beaver, M. R., Jaoui, M., Docherty, K. S., and Edney, E. O.: Secondary organic aerosol characterisation at field sites across the United States during the spring-summer period, Int. J. Environ. An. Ch., 93, 1084-1103, 2013.

Lewis, C. W., Klouda, G. A., and Ellenson, W. D.: Radiocarbon measurement of the biogenic contribution to summertime
PM-2.5 ambient aerosol in Nashville, TN, Atmos. Environ., 38 , 6053-6061, doi:10.1016/j.atmosenv.2004.06.011, 2004.

Liu, S., Ahlm, L., Day, D. A., Russell, L. M., Zhao, Y., Gentner, D. R., Weber, R. J., Goldstein, A. H., Jaoui, M., Offenberg, J. H., Kleindienst, T. E., Rubitschun, C., Surratt, J. D., Sheesley, R. J., and Scheller, S.: Secondary organic aerosol formation from fossil fuel sources contribute majority of summertime organic mass at Bakersfield, J. Geophys. Res.-Atmos., 117, D00V26, doi:10.1029/2012JD018170, 2012.

Mao, J., Ren, X., Zhang, L., Van Duin, D. M., Cohen, R. C., Park, J.-H., Goldstein, A. H., Paulot, F., Beaver, M. R., Crounse, J. D., Wennberg, P. O., DiGangi, J. P., Henry, S. B., Keutsch, F. N., Park, C., Schade, G. W., Wolfe, G. M., Thornton, J. A., and Brune, W. H.: Insights into hydroxyl measurements and atmospheric oxidation in a California forest, Atmos. Chem. Phys., 12, 8009-8020, doi:10.5194/acp-12-8009-2012, 2012.

Markovic, M., VandenBoer, T., Baker, K., Kelly, J., and Murphy, J.: Measurements and modeling of the inorganic chemical composition of fine particulate matter and associated precursor gases in California's San Joaquin Valley during CalNex 2010, J. Geophys. Research-Atmos., 119, 6853-6866, doi:10.1002/2013JD021408, 2014.

Offenberg, J. H., Lewandowski, M., Edney, E. O., Kleindienst, T. E., and Jaoui, M.: Influence of Aerosol Acidity on the Formation of Secondary Organic Aerosol from Biogenic Precursor Hydrocarbons, Environ. Sci. Technol., 43, 7742-7747, doi:10.1021/es901538e, 2009.

Ormeño, E., Gentner, D. R., Fares, S., Karlik, J., Park, J. H., and Goldstein, A. H.: Sesquiterpenoid emissions from agricultural crops: correlations to monoterpenoid emissions and leaf terpene content, Environ. Sci. Technol., 44, 3758-3764, 2010.

Pye, H. O. T. and Pouliot, G. A.: Modeling the Role of Alkanes, Polycyclic Aromatic Hydrocarbons, and Their Oligomers in Secondary Organic Aerosol Formation, Environ. Sci. Technol., 46, 6041-6047, doi:10.1021/es300409w, 2012.

Pye, H. O. T., Pinder, R. W., Piletic, I. R., Xie, Y., Capps, S. L., Lin, Y.-H., Surratt, J. D., Zhang, Z., Gold, A., and Luecken, D. J.: Epoxide pathways improve model predictions of isoprene markers and reveal key role of acidity in aerosol formation, Environ. Sci. Technol., 47, 11056-11064, 2013.

Robinson, A. L., Donahue, N. M., Shrivastava, M. K., Weitkamp, E. A., Sage, A. M., Grieshop, A. P., Lane, T. E., Pierce, J. R., and Pandis, S. N.: Rethinking organic aerosols: Semivolatile emissions and photochemical aging, Science, 315, 1259-1262, 2007.

Rollins, A., Browne, E., Min, K.-E., Pusede, S., Wooldridge, P., Gentner, D., Goldstein, A., Liu, S., Day, D., and Russell, L.: Evidence for $\mathrm{NO}_{x}$ control over nighttime SOA formation, Science, 337, 1210-1212, 2012.

Ryerson, T. B., Andrews, A. E., Angevine, W. M., Bates, T. S., Brock, C. A., Cairns, B., Cohen, R. C., Cooper, O. R., de Gouw, J. A., Fehsenfeld, F. C., Ferrare, R. A., Fischer, M. L., Flagan, R. C., Goldstein, A. H., Hair, J. W., Hardesty, R. M., Hostetler, C. A., Jimenez, J. L., Langford, A. O., McCauley, E., McKeen, S. A., Molina, L. T., Nenes, A., Oltmans, S. J., Parrish, D. D., Pederson, J. R., Pierce, R. B., Prather, K., Quinn, P. K., Seinfeld, J. H., Senff, C. J., Sorooshian, A., Stutz, J., Surratt, J. D., Trainer, M., Volkamer, R., Williams, E. J., and Wofsy, S. C.: The 2010 California Research at the Nexus of Air Quality and Climate Change 
(CalNex) field study, J. Geophys. Res.-Atmos., 118, 5830-5866, doi:10.1002/jgrd.50331, 2013.

Sarwar, G., Fahey, K., Kwok, R., Gilliam, R. C., Roselle, S. J., Mathur, R., Xue, J., Yu, J., and Carter, W. P. L.: Potential impacts of two $\mathrm{SO}_{2}$ oxidation pathways on regional sulfate concentrations: Aqueous-phase oxidation by $\mathrm{NO}_{2}$ and gas-phase oxidation by Stabilized Criegee Intermediates, Atmos. Environ., 68, 186-197, doi:10.1016/j.atmosenv.2012.11.036, 2013.

Shilling, J. E., Zaveri, R. A., Fast, J. D., Kleinman, L., Alexander, M. L., Canagaratna, M. R., Fortner, E., Hubbe, J. M., Jayne, J. T., Sedlacek, A., Setyan, A., Springston, S., Worsnop, D. R., and Zhang, Q.: Enhanced SOA formation from mixed anthropogenic and biogenic emissions during the CARES campaign, Atmos. Chem. Phys., 13, 2091-2113, doi:10.5194/acp-13-20912013, 2013.

Simon, H. and Bhave, P. V.: Simulating the Degree of Oxidation in Atmospheric Organic Particles, Environ. Sci. Technol., 46, 331339, doi:10.1021/es202361w, 2012.

Skamarock, W. C., Klemp, J. B., Dudhia, J., Gill, D. O., Barker, D. M., Duda, M. G., Huang, X., Wang, W., and Powers, J. G.: A description of the Advanced Reserch WRF version 3., NCAR Technical Note NCAR/TN-475+STR, 2008.

Steiner, A. L., Cohen, R. C., Harley, R. A., Tonse, S., Millet, D. B., Schade, G. W., and Goldstein, A. H.: VOC reactivity in central California: comparing an air quality model to ground-based measurements, Atmos. Chem. Phys., 8, 351-368, doi:10.5194/acp-8351-2008, 2008.

Stroud, C. A., Liggio, J., Zhang, J., Gordon, M., Staebler, R. M., Makar, P. A., Zhang, J., Li, S. M., Mihele, C., and Lu, G.: Rapid organic aerosol formation downwind of a highway: Measured and model results from the FEVER study, J. Geophys. Res.Atmos., 119, 1663-1679, 2014.

Stuiver, M.: International agreements and the use of the new oxalic acid standard, Radiocarbon, 25, 793-795, 1983.

Tan, Y., Carlton, A. G., Seitzinger, S. P., and Turpin, B. J.: SOA from methylglyoxal in clouds and wet aerosols: measurement and prediction of key products, Atmos. Environ., 44, 5218-5226, doi:10.1016/j.atmosenv.2010.08.045, 2010.

US Environmental Protection Agency: 2011 National Emissions Inventory, version 1 Technical Support Document, available at: http://www.epa.gov/ttn/chief/net/2011nei/2011_nei_tsdv1_ draft2_june2014.pdf (last access: 8 May 2015), edited by: Agency, U. E. P., 2014.
Wagstrom, K. M., Baker, K. R., Leinbach, A. E., and Hunt, S. W.: Synthesizing Scientific Progress: Outcomes from US EPA's Carbonaceous Aerosols and Source Apportionment STAR Grants, Environ. Sci. Technol., 48, 10561-10570, 2014.

Washenfelder, R. A., Young, C. J., Brown, S. S., Angevine, W. M., Atlas, E. L., Blake, D. R., Bon, D. M., Cubison, M. J., de Gouw, J. A., Dusanter, S., Flynn, J., Gilman, J. B., Graus, M., Griffith, S., Grossberg, N., Hayes, P. L., Jimenez, J. L., Kuster, W. C., Lefer, B. L., Pollack, I. B., Ryerson, T. B., Stark, H., Stevens, P. S., and Trainer, M. K.: The glyoxal budget and its contribution to organic aerosol for Los Angeles, California, during CalNex 2010, J. Geophys. Res.-Atmos., 116, D00V02, doi:10.1029/2011jd016314, 2011.

Yarwood, G., Rao, S., Yocke, M., and Whitten, G. Z.: Updates to the carbon bond chemical mechanism: CB05, ENVIRON International Corporation, Novato, CA, 2005.

Zhang, H., Chen, G., Hu, J., Chen, S.-H., Wiedinmyer, C., Kleeman, M., and Ying, Q.: Evaluation of a seven-year air quality simulation using the Weather Research and Forecasting (WRF)/Community Multiscale Air Quality (CMAQ) models in the eastern United States, Sci. Total Environ., 473, 275-285, 2014a.

Zhang, X., Cappa, C. D., Jathar, S. H., McVay, R. C., Ensberg, J. J., Kleeman, M. J., and Seinfeld, J. H.: Influence of vapor wall loss in laboratory chambers on yields of secondary organic aerosol, $\mathrm{P}$. Natl. Acad. Sci. USA, 111, 5802-5807, 2014b.

Zhao, Y., Kreisberg, N. M., Worton, D. R., Isaacman, G., Gentner, D. R., Chan, A. W., Weber, R. J., Liu, S., Day, D. A., and Russell, L. M.: Sources of organic aerosol investigated using organic compounds as tracers measured during CalNex in Bakersfield, J. Geophys. Res.-Atmos., 118, 11388-11398, 2013.

Zhao, Y., Hennigan, C. J., May, A. A., Tkacik, D. S., de Gouw, J. A., Gilman, J. B., Kuster, W. C., Borbon, A., and Robinson, A. L.: Intermediate-Volatility Organic Compounds: A Large Source of Secondary Organic Aerosol, Environ. Sci. Technol., 48, 1374313750, 2014.

Zotter, P., El-Haddad, I., Zhang, Y., Hayes, P. L., Zhang, X., Lin, Y. H., Wacker, L., Schnelle-Kreis, J., Abbaszade, G., and Zimmermann, R.: Diurnal cycle of fossil and nonfossil carbon using radiocarbon analyses during CalNex, J. Geophys. Res.-Atmos. 119, 6818-6835, doi:10.1002/2013JD021114, 2014. 